\title{
Dissymmetry at the Border: Wild Food and Medicinal Ethnobotany of Slovenes and Friulians in Northeast Italy
}

\author{
Giulia Mattalia $^{1,2, *}$, Renata Sõukand ${ }^{2}$, Paolo Corvo $^{1}$, and Andrea Pieroni ${ }^{1}$ \\ ${ }^{1}$ University of Gastronomic Sciences, Piazza Vittorio Emanuele 9, Pollenzo, I-12042, Bra (CN), \\ Italy \\ ${ }^{2} \mathrm{Ca}$ ' Foscari University of Venice, Via Torino 155 , I-30172 Mestre (VE), Italy
}

*Corresponding author; e-mail: giulia.mattalia@unive.it

Cross-cultural and cross-border research represents a valuable tool for addressing traditional plant knowledge variability and change. An ethnobotanical field study was carried out during late spring 2018 within two culturally and linguistically distinct communities (Friulian and Slovenian speakers) in Friuli Venezia Giulia, Northeast Italy. Data were gathered via semi-structured interviews with 32 local inhabitants regarding the use of wild and semi-domesticated food and medicinal plants. We recorded 108 botanical taxa, of which 79 were common to both communities. Despite a common ecological landscape and an overlap in the overall used taxa, some differences were recorded for the most commonly utilized taxa. This indicates that the culture and language of minorities may have played an important role in preserving biocultural identity and customs. Our study shows how dissymmetry was shaped by the different distances of the two groups to the dominant standard Italian mainstream over the last few centuries and how cultural identity is actually constructed in relation to a dominant cultural code. Future studies should address the 
This is the postprint version of the article:

Mattalia, G., Soukand, R., Corvo, P., \& Pieroni, A. (2020 Dissymmetry at the Border: Wild Food and Medicinal Ethnobotany of Slovenes and Friulians in Northeast Italy Economic Botany, 10.1007/s12231-020-09488-y.

strategies of biocultural adaptation and resilience in multiethnic and multilingual crossroad regions.

\section{Dissimmetria al Confine: Etnobotanica di Sloveni e Friulani in Friuli Venezia Giulia. La}

ricerca transculturale e transfrontaliera rappresenta uno strumento prezioso per affrontare la variabilità e l'evoluzione delle conoscenze tradizionali relative alle piante. Uno studio etnobotanico è stato condotto durante la tarda primavera 2018 in due comunità culturalmente e linguisticamente distinte (friulani e sloveni) del Friuli Venezia Giulia. I dati sono stati raccolti attraverso interviste semistrutturate con 32 persone del luogo riguardanti l'uso di piante e piante medicinali spontanee e semi-spontanee. Abbiamo registrato 108 taxa botanici, di cui 79 comuni ad entrambe le comunità. Nonostante un paesaggio simile molti taxa comuni, sono state registrate alcune differenze sostanziali tra i taxa più comunemente utilizzati. Ciò indica che la cultura e il linguaggio delle minoranze possono aver svolto un ruolo importante nel preservare l'identità bioculturale a livello di comunità. Questo studio mostra come, negli ultimi secoli, la dissimmetria sia stata modellata dalle diverse distanze dei due gruppi rispetto allo standard italiano dominante e come l'identità culturale sia stata effettivamente costruita in relazione al codice culturale dominante. Studi futuri dovrebbero approfondire le strategie di adattamento e resilienza bioculturale in regioni multietniche e multilingue come il Friuli Venezia Giulia

Key Words: Biocultural diversity; ethnobotany; Friuli; Italy; linguistic minorities 
This is the postprint version of the article:

Mattalia, G., Soukand, R., Corvo, P., \& Pieroni, A. (2020 Dissymmetry at the Border: Wild Food and Medicinal Ethnobotany of Slovenes and Friulians in Northeast Italy Economic Botany, 10.1007/s12231-020-09488-y.

\section{Introduction}

Approaching complex systems of traditional plant knowledge from a cross-cultural and crossborder perspective is a powerful tool for exploring changes and variability of plant uses. Borders are not just non-places (Augè 1992); rather, "they simultaneously belong to two parts, while being defined by neither one entirely" (Marsico 2016). Indeed, borders are defined not only in geographic terms, but also in cultural terms. While geographic borders dramatically shape the practice of plant use (Sõukand and Pieroni 2016), language, as the primary means for human communication, and the preservation of cultural identity, has also been proven to be a powerful element for sustaining local ecological knowledge and practices (Maffi 2005; Menendez-Baceta et al. 2015; Pieroni and Quave 2005). Yet, in the case of closely related languages, linguistic differences may not be sufficient to prevent interpenetration of exogenous ecological practices even over long distances, possibly due to a recent sharing of a socio-cultural environment (Pieroni and Sõukand 2017, 2018).

At the same time, Menendez-Baceta et al. (2015) stressed the importance of the reinforcement of cultural identity in maintaining traditional knowledge. Also, other ethnobotanical studies conducted among linguistic minorities in Europe have shown the importance of traditional ecological knowledge related to wild food and medicinal plants as not only a tool for cultural negotiation but also a cultural identity strengthener (Ceuterick et al. 2008; Maxia et al. 2008; Pieroni et al. 2010). Therefore, it is important to understand the mechanisms of the influence of language and cultural identity in shaping traditional ecological knowledge (TEK). Indeed, the spatial distribution and changes of TEK related to plants in border areas is also crucial for 
This is the postprint version of the article:

Mattalia, G., Soukand, R., Corvo, P., \& Pieroni, A. (2020 Dissymmetry at the Border: Wild Food and Medicinal Ethnobotany of Slovenes and Friulians in Northeast Italy Economic Botany, 10.1007/s12231-020-09488-y.

discussing the impact of national and local policies on the overall resilience of TEK; how they shaped cultural negotiations through centripetal and centrifugal forces.

Within this framework, we selected two linguistic groups, located in Friuli Venezia Giulia, the northeast Italian region that shares its borders with Austria and Slovenia: the dominant Friulians, who number approximately 600,000 speakers (most of them able to use the language only passively, given the large interface both linguistically and culturally with standard Italian and Venetian languages/dialects), and the Slovenes of the "Slavia Friuliana" or "Benečija" hilly/mountainous area, who number about 7,000 speakers. The region itself has long represented a geopolitical crossroads between Northern and Southern, and Western and Eastern Europe. This complexity has resulted in linguistic diversity, in which the majority of the population speaks Friulian (which on the Italian scale is considered a minority language), but there are also Slovenian speakers of the Benečija area (including Nediško, Terško, and Rezjansko dialects) as well as German (Carinthian/Austrian dialect) speakers. Therefore, the liminal region of Friuli Venezia Giulia contains borders itself, both cultural (with the Friulians) and geographic (formerly with Yugoslavia, and currently with Slovenia). While there are some older publications available on Friulian ethnobotany, including Appi et al. 1979, Coassini-Lokar et al. 1983, Costantini 1941, and Oman 1992, more recent studies have highlighted only the uses of wild plants in the neighboring part of the Alps including Austria, Switzerland, and Slovenia (Abbet et al. 2014; Christanell et al. 2010; Lumpert and Kreft 2017; Schunko and Vogl 2010).

The Nediško-speaking population provides a good example of a community exhibiting geographic, linguistic, and cultural borders. It was effectively isolated from its linguistically Slovenian neighbors by the Slovenian border for over 140 years, between 1866, when the Natisone 
This is the postprint version of the article:

Mattalia, G., Soukand, R., Corvo, P., \& Pieroni, A. (2020 Dissymmetry at the Border: Wild Food and Medicinal Ethnobotany of Slovenes and Friulians in Northeast Italy Economic Botany, 10.1007/s12231-020-09488-y.

Valleys joined Italy, and 2007, when Slovenia joined the Schengen area within the European Union. The community differs from its geographically accessible neighbors in language, and it maintains and promotes its own cultural identity.

As part of the project "Biodiversity and Ecosystem Services in Sacred Natural Sites," this study was also designed to explore the effects of sacred natural sites, that is, "portions of land or water holding spiritual significance for people and communities" (Wild and McLeod 2008) and, in particular, the famous shrine "Santuario della Beata Vergine di Castelmonte," on the TEK of local inhabitants. Indeed, while the role of sacred natural sites in biodiversity conservation is wellrecognized (Frascaroli et al. 2016; Verschuuren 2012), little research is available on the effects of such sacred natural sites on the ecological knowledge of the people living in the surrounding area (Frascaroli and Verschuuren 2016).

The aim of the study was to advance the understanding of the contribution of linguistic and cultural identity to TEK related to wild and semi-domesticated plants in Friuli Venezia Giulia through four main objectives:

1. Record TEK on wild and semi-domesticated food and medicinal plants among Friulian speakers of Torreano and Nediško speakers of the Natisone Valleys;

2. Identify similarities and differences between the two communities;

3. Explore the possible role of the cultural and linguistic borders in affecting TEK within the same ecological niche; and

4. Verify whether the sacred natural site of Castelmonte has had an effect on the traditional ecological knowledge of people living in the surrounding area. 
This is the postprint version of the article:

Mattalia, G., Soukand, R., Corvo, P., \& Pieroni, A. (2020 Dissymmetry at the Border: Wild Food and Medicinal Ethnobotany of Slovenes and Friulians in Northeast Italy Economic Botany, 10.1007/s12231-020-09488-y.

\section{Material and Methods}

The study was conducted in selected villages of Friuli Venezia Giulia, which is a political region located in northeastern Italy. In the region, there are three recognized linguistic minorities including Friulian, Slovenian, and German (Carinthian) languages (see Figure 1).

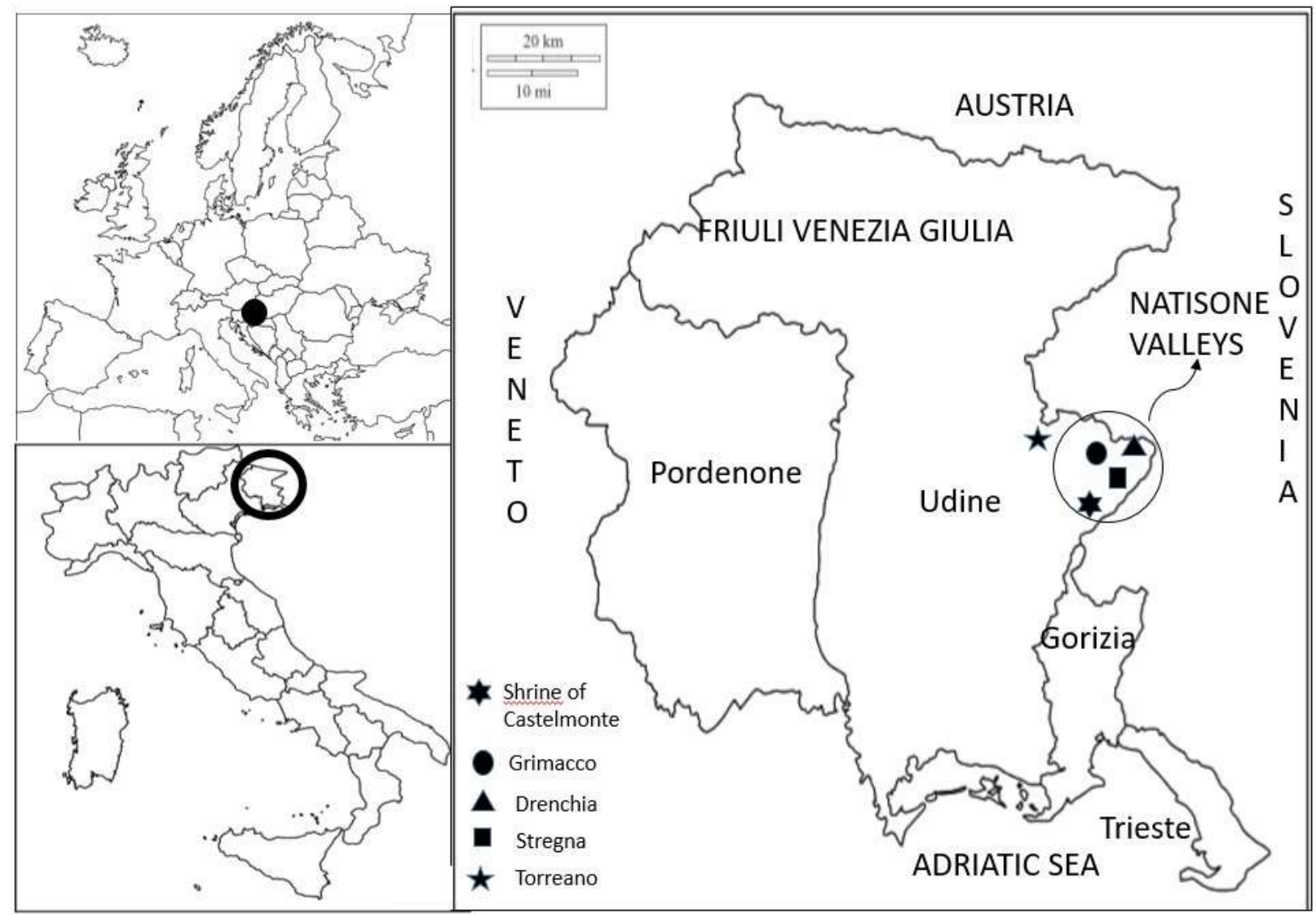

Study Area

High precipitation and persistent cloudiness characterize the study area, especially at higher altitudes $\left(1,300 \mathrm{~mm}\right.$ rain/year). The average temperature in Torreano ranges between $2.6^{\circ} \mathrm{C}$ (January) and $21.7^{\circ} \mathrm{C}$ (July), while in the Natisone Valleys it ranges between $0^{\circ} \mathrm{C}$ (January) and 
This is the postprint version of the article:

Mattalia, G., Soukand, R., Corvo, P., \& Pieroni, A. (2020 Dissymmetry at the Border: Wild Food and Medicinal Ethnobotany of Slovenes and Friulians in Northeast Italy Economic Botany, 10.1007/s12231-020-09488-y.

$18.6^{\circ} \mathrm{C}$ (July). The climate is characterized by cool summers and cool winters and thus it corresponds to a Cfb climate according to Köppen classification (ARPA 2014). Interviews with Friulian speakers were conducted in Torreano. This municipality is in a closed valley starting at 150 masl and climbing up with its small villages to Mount Joanaz (1,167 masl). Torreano has around 2,100 inhabitants who live mostly in the center and in the parish of Prestento. A Slavic dialect is spoken in the scarcely inhabited villages of Masarolis (660 masl), Reant (660 masl), and Tamoris (805 masl). Due to the low number of inhabitants, we could not carry out the study in this area; however, we interviewed an 82-year-old man living in Tamoris. This interview was not included in the quantitative data analysis as, despite belonging to the Torreano municipality, his first language was a Slovenian dialect close to Nediško. Instead, results from his interview will be qualitatively discussed separately. Interviews with Nediško speakers were conducted in several villages within the municipalities of Grimacco (Garmak), Drenchia (Dreka), and Stregna (Srednje). Altitude varies between 200 masl and 987 masl. These municipalities number 333, 118, 345 inhabitants, respectively, spread out in many villages of a few houses each. In both study areas, a massive rural depopulation took place during the last century and now only 30\% of the 1921 population remains. After WWII, many men left for Belgium and France to work in the mines (Cozzi 2009). Most of them returned to Friuli Venezia Giulia a few years later, but some families moved to Belgium.

\section{The Project Framework}

This research was conducted within the framework of the project "Biodiversity and Ecosystem Services in Sacred Natural Sites" funded by the Italian Ministry of Education, 
This is the postprint version of the article:

Mattalia, G., Soukand, R., Corvo, P., \& Pieroni, A. (2020 Dissymmetry at the Border: Wild Food and Medicinal Ethnobotany of Slovenes and Friulians in Northeast Italy Economic Botany, 10.1007/s12231-020-09488-y.

University and Research. Four research institutions contributed to different aspects of this topic. Therefore, we selected the sacred natural site of "Santuario della Beata Vergine di Castelmonte" from the database that was developed by partner institutions. Then, we selected two communities living close to and distant from the sacred natural site. We consider the community of Torreano to be close as it lies within $10 \mathrm{~km}$ of the shrine and the communities of the Natisone Valleys to be distant as they lie between 15 and $20 \mathrm{~km}$ from the sacred natural site.

The Sacred Natural Site of Castelmonte

Within the Natisone Valleys, at the Slovenian border, lies the oldest shrine of Friuli Venezia Giulia, dating back to the 5th century. This place is well-known among both Friulians (who call this sacred place Madona di Mont) and Nediško speakers (who call the shrine Stara Gora). This sacred natural site, besides being an important center of pilgrimage for many centuries, has an intimate cultural legacy for Nediško speakers as one of the oldest manuscripts of their language, reporting the prayers "Our Father," "Hail Mary," and "Apostles' Creed," was found here around 1960.

\section{Historical Background}

Friulian and Nediško speakers have coexisted within the same region for many centuries. Indeed, the Natisone Valleys belong to a historical region of Friuli Venezia Giulia called Benečija, which has been part of Italy since 1866. It also includes Torre Valley and Resia Valley where the main languages are Terško and Rezjansko, respectively, both of Slavic origin (Toso 2008). The first evidence of the presence of Slavic speakers in the Natisone Valleys dates to 720 (Bonessa 
This is the postprint version of the article:

Mattalia, G., Soukand, R., Corvo, P., \& Pieroni, A. (2020 Dissymmetry at the Border: Wild Food and Medicinal Ethnobotany of Slovenes and Friulians in Northeast Italy Economic Botany, 10.1007/s12231-020-09488-y.

2013). As with the whole region of Friuli Venezia Giulia, the Natisone Valleys were included in the Republic of Venice between 1419 and 1797. Indeed, Nediško speakers were considered as "fedelissimi" ("very faithful") to the Republic of Venice and, as such, they received important military and fiscal benefits (Bonessa 2013). During that time, they could freely develop and preserve their own culture and language under a favorable regime. Between 1797 and 1866 this territory was part of the Hapsburg Empire. In 1866, when, through a plebiscite, the inhabitants of these valleys joined the nascent Kingdom of Italy, Nediško speakers became isolated with very strong ties within the community, and very wary of outsiders (Šiškovič 1978). Indeed, the intellectuals read Slovenian newspapers coming cross-border as, despite the new italophone administration, the Slovenian language was still tolerated (Šiškovič 1978). A few years later, the process of Italianization turned more severe, and Nediško could only be spoken within the home, in the absence of witnesses, and in church (Šiškovič 1978). In 1933, the archbishop of Udine prohibited the use of the Slovenian language in churches as well. Generally, the inhabitants of Benečija regarded both the administration and school as something "strange" and "foreign," and this caused a counterbalanced psychological reaction (Šiškovič 1978) as they also felt different from neighboring Friulians (Podrecca 1884). According to Šiškovič (1978), the preservation of Nediško is due to geographic isolation, deep linguistic self-identification, formal and informal contacts with cross-border Slovenians, and the constant presence of Slovenian speaking priests, representing the most apparent and crucial national element. Italianization lasted until WWII, and at the end of the war, on 14 September 1947, a new border was established a few hundred meters away from the village of Topolò (Grimacco). The border separated this village from its fields, but also cut off family ties that were now beyond the frontier in Yugoslavia. Until 1954, the border 
This is the postprint version of the article:

Mattalia, G., Soukand, R., Corvo, P., \& Pieroni, A. (2020 Dissymmetry at the Border: Wild Food and Medicinal Ethnobotany of Slovenes and Friulians in Northeast Italy Economic Botany, 10.1007/s12231-020-09488-y.

was impenetrable (Cozzi 2009). Later, local inhabitants were provided with a pass to cross the border and resume their agricultural activities (Cozzi 2009). Nevertheless, the border lasted for six decades. On 21 December 2007, the Republic of Slovenia, constituted in 1991, joined the Schengen area and the frontiers were opened.

\section{Data Collection}

Fieldwork was carried out in May 2018 during which 32 in-depth interviews were conducted, including 16 among Friulian speakers of Torreano, 15 among Nediško speakers of the Natisone Valleys, and one with a Slavic speaker from a Slovenian village within the municipality of Torreano (his responses were not included in the comparison of the communities, but will be addressed qualitatively). Purposive sampling and snowball methods were applied in the selection of informants. Within the "qualitative" sample of 31 interviews, 19 were given by women and 12 by men, ranging in age from 31 to 101 years (mean age 72 years). The Code of Ethics of the International Society of Ethnobiology (ISE 2008) was strictly followed, and prior informed consent was received orally. Interviews were conducted in the Italian language; however, plant names were given mainly in Friulian and Nediško. We gathered qualitative and quantitative data about local wild and semi-domesticated plants gathered nowadays or in the past, for medicinal and culinary purposes, as well as recipes, plant parts used, and modes of preparation and consumption.

Subsequently, informants were asked to indicate remedies for treating illnesses by naming each part of the body. Specifically, in this research, in the domain of semi-domesticated taxa, we included plants that were sometimes kept close to home and in vegetable gardens, for easier 
This is the postprint version of the article:

Mattalia, G., Soukand, R., Corvo, P., \& Pieroni, A. (2020 Dissymmetry at the Border: Wild Food and Medicinal Ethnobotany of Slovenes and Friulians in Northeast Italy Economic Botany, 10.1007/s12231-020-09488-y.

accessibility. Indeed, some informants reported them as wild because these plants were often originally taken from the wild and transplanted or seeded closer to the house without much care by the owner. Interviews were semi-structured, and an in-depth conversation was conducted when possible. Whenever possible, informants were asked to show mentioned plants around the house in order to harvest voucher specimens for herbarium preparation. The mentioned species were collected, when available, and identified according to the "Flora d'Italia" (Pignatti 1982). Voucher specimens are deposited at the University of Gastronomic Sciences and bear the numbers UNISGFRI001-UNISGFRI035. Taxonomic identification, botanical nomenclature, and family assignments followed the Flora Europaea (Tutin et al. 1964), The Plant List database (2013), and the Angiosperm Phylogeny Group IV (Stevens 2015), respectively.

\section{Data Analysis}

Data for the 31 interviews were compiled in an MSExcel database and structured in the form of emic categories. Following Sõukand et al. (2013), we used emic categories for both medicinal and food uses of plants. The emic perspective, as applied to our categories, "results from studying behavior as from inside the system" (Pike 1967). We also calculated the number of food and medicinal uses for comparison. Following González-Tejero et al. (2008), we calculated Jaccard Similarity Indices as follows:

$$
\mathrm{JI}(\%)=(\mathrm{C} /(\mathrm{A}+\mathrm{B}-\mathrm{C})) \times 100
$$


This is the postprint version of the article:

Mattalia, G., Soukand, R., Corvo, P., \& Pieroni, A. (2020 Dissymmetry at the Border: Wild Food and Medicinal Ethnobotany of Slovenes and Friulians in Northeast Italy Economic Botany, 10.1007/s12231-020-09488-y.

where A represents the number of taxa/Use Instances in sample A, B is the number of taxa/Use Instances in sample $\mathrm{B}$, and $\mathrm{C}$ is the number of taxa/Use Instances common to $\mathrm{A}$ and $\mathrm{B}$.

In addition, to analyze the effect of distance to the sacred natural site, we calculated the number of taxa mentioned in the close and distant communities.

\section{Results and Discussion}

We recorded current and past uses for 108 taxa belonging to 43 plant families (see Table 1 in the Appendix [Electronic Supplementary Material, ESM]), of which the most well represented were Asteraceae (18 taxa), Rosaceae (12 taxa), and Lamiaceae (9 taxa).

Ninety-one plants were used among Friulian speakers of Torreano, while eighty-two were used among Nediško speakers of the Natisone Valleys. Seventy-nine taxa were common to the two linguistic groups (corresponding to $73 \%$ of the total). The taxa overlaps (expressed through Jaccard Similarity Indices) were relatively high for food and low for medicinal taxa (Figure 2) compared to our earlier results for post-Soviet regions (Pieroni and Sõukand 2017, 2018; Sõukand and Pieroni 2016). 
This is the postprint version of the article:

Mattalia, G., Soukand, R., Corvo, P., \& Pieroni, A. (2020 Dissymmetry at the Border: Wild Food and Medicinal Ethnobotany of Slovenes and Friulians in Northeast Italy Economic Botany, 10.1007/s12231-020-09488-y.

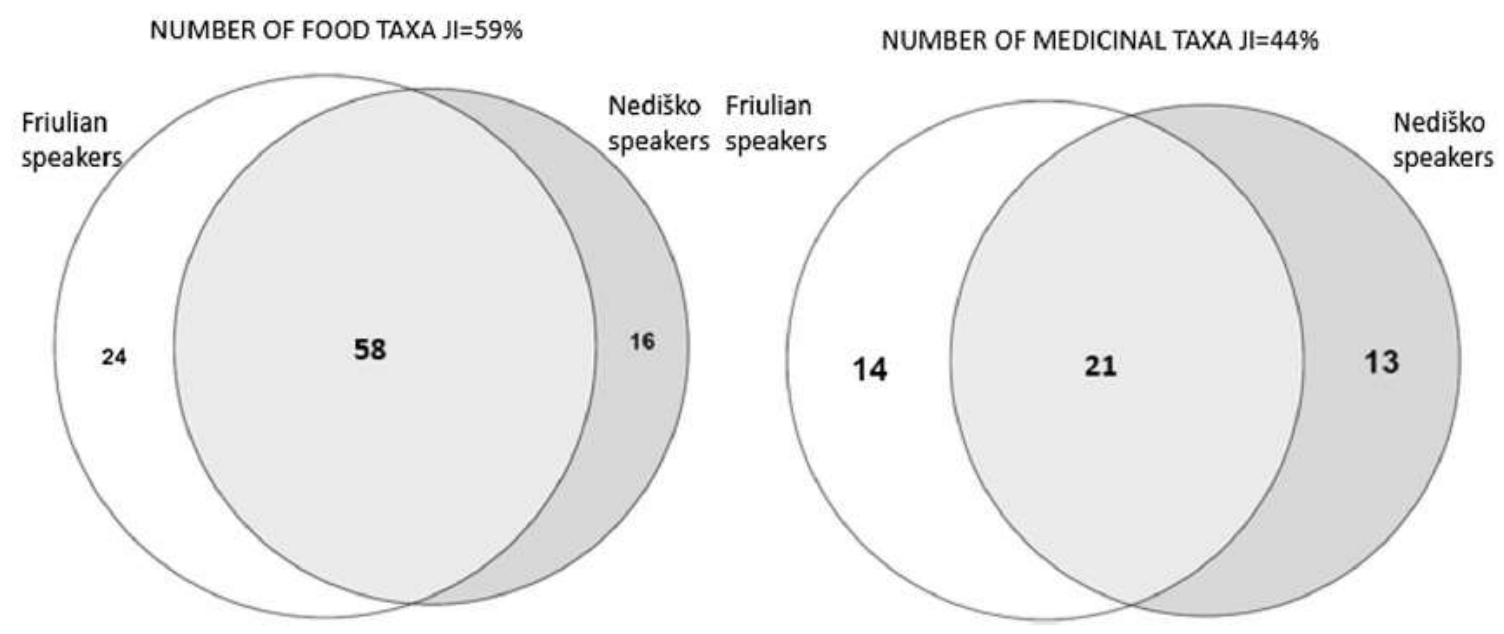

Fig. 2. Venn diagrams of current food and medicinal taxa in both communities and Jaccard Similarity Index.

For both communities, the most popular taxon used was Malva sylvestris L. (69 citations, of which 11 mentioned 6 food uses and 58 referred to 13 medicinal uses). Fresh or dried aerial parts, especially flowers, are prepared as infusions, fomentations, decoctions, or poultices. Their use is widespread both in Torreano and in the Natisone Valleys.

This was followed by Sambucus nigra L. (66 citations, of which 27 mentioned 5 food uses and 39 referred to 4 medicinal uses), which is used for both food and medicinal preparations, mainly as syrup. Flowers can be used dried or fresh and are common in both Torreano and the Natisone Valleys. Other common taxa include Foeniculum vulgare Mill., Castanea sativa Mill., and Urtica dioica L. The most widespread uses among the Friulian speakers of Torreano include Foeniculum vulgare for omelet preparation (> 80\% of informants), battered and fried Robinia pseudoacacia L. (> 80\% of interviewees), and Mentha spp. for omelet preparation (75\% of the interviewees). The most prevalent uses among Nediško speakers of the Natisone Valleys include Tanacetum parthenium (L.) Sch.Bip. for omelet preparation (> 90\% of interviewees), Juglans 
This is the postprint version of the article:

Mattalia, G., Soukand, R., Corvo, P., \& Pieroni, A. (2020 Dissymmetry at the Border: Wild Food and Medicinal Ethnobotany of Slovenes and Friulians in Northeast Italy Economic Botany, 10.1007/s12231-020-09488-y.

regia L. for dessert preparation (> 85\% of interviewees), and Levisticum officinale W.D.J.Koch prepared in omelets (> 85\% of interviewees).

We found greater differences between the numbers of emic categories (Figure 3). Among the two linguistic groups, the most popular emic food category in which wild plants were represented was that of infusions in grappa (46 used taxa in total, 28 mentioned in Torreano, 34 mentioned in the Natisone Valleys). This was followed by the categories of omelets (41 taxa in total, 32 mentioned in Torreano, 31 mentioned in the Natisone Valleys), litùn-a mix of wild leafy plants - (18 taxa only mentioned in Torreano), and soup (18 taxa mentioned in the Natisone Valleys, 4 of which were also mentioned in Torreano).

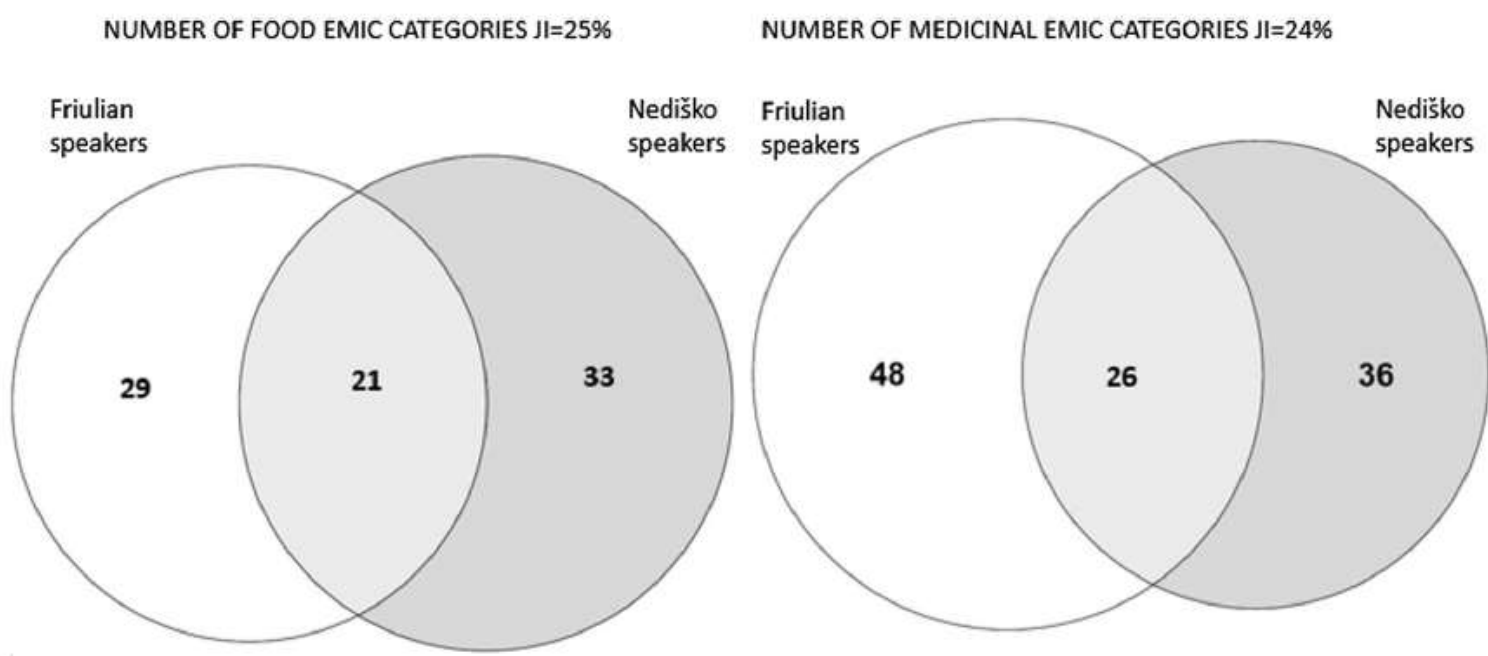

Fig. 3. Venn diagrams of food and medicinal emic caregories in both communities and Jaccard Similarity Index.

Medicinal preparations mentioned include infusions (25 uses), local applications (4 uses), coffee preparations ( 2 uses), preparations in warm olive oil or pork fat (4 and 1 use, respectively), infusions in grappa (an Italian schnapps) to obtain ointments (3 uses) or as such (2 uses), decoctions (6 uses), distillates ( 2 uses), boiled preparations in warm milk (2 uses) or as such (1 
This is the postprint version of the article:

Mattalia, G., Soukand, R., Corvo, P., \& Pieroni, A. (2020 Dissymmetry at the Border: Wild Food and Medicinal Ethnobotany of Slovenes and Friulians in Northeast Italy Economic Botany, 10.1007/s12231-020-09488-y.

use), syrup preparations ( 2 uses), chewing of raw plants ( 2 uses), and application of a poultice (1 use). The most common preparations among Friulian speakers are the same as those among Nediško speakers, namely infusions as sedatives (5 taxa for each linguistic group) and infusions for treating flu and cough (1 taxon for each group). Among Nediško speakers there are fewer medical emic categories, while there are slightly more taxa used for medicinal preparation. Our hypothesis is that there was less accessibility to doctors and grappa (a mixture of different plants) was often the main treatment, as it was considered a panacea.

Versatile taxa include Malva sylvestris (19 uses) and the leaves of Salvia officinalis, which were used both for medicinal (8 uses) and gastronomic (4 uses) preparations in both communities. The aerial parts and buds of Taraxacum campylodes G.E.Haglund were mainly considered for food preparation (9 uses) while the roots and flowers were used for medicinal preparations such as detox decoctions and a beneficial wine, as well as a syrup for treating cough. Dried seeds and flowers or fresh aerial parts of Foeniculum vulgare, were used in 11 different preparations of which 6 were medicinal and 5 gastronomic. Urtica dioica was mentioned as an ingredient for six food preparations by both Friulian and Nediško speakers, while medicinal uses of this plant were mainly recorded among Friulian speakers (4 uses). Castanea sativa was recorded as an ingredient in 10 different food recipes.

Overall, the differences between the two communities are quite small, as on average each informant in Torreano mentioned 44 detailed uses and 31 taxa, and in the Natisone Valleys the numbers were only slightly higher (46.5 detailed uses and 32 taxa). 
This is the postprint version of the article:

Mattalia, G., Soukand, R., Corvo, P., \& Pieroni, A. (2020 Dissymmetry at the Border: Wild Food and Medicinal Ethnobotany of Slovenes and Friulians in Northeast Italy Economic Botany, 10.1007/s12231-020-09488-y.

\section{Commonly Used Plants}

When considering only the 20 most used plants in each community, remarkable differences appear. Indeed, the inhabitants of the Natisone Valleys use plants more consistently, as the top 20 plants are used by at least two-thirds of the interviewees (10 out of 15 informants). Conversely, only 13 plant taxa were used by the same number of Friulian interviewees. This could be related to a stronger cultural identity due to their geographic and cultural isolation. We observed that, among the Nediško speakers, fruits (both fruit trees such as Castanea or Juglans, and forest fruits such as Rubus idaeus L., Rubus ulmifolius Schott, and Vaccinium myrtillus L.) are important food resources. These types of taxa are not very relevant to the Friulian community, which has better access to a wider variety of resources due to their geographic location and shared cultural background with bigger towns in the surrounding area.

The interview with the 82-year-old male Slavic speaker from Tamoris (Torreano municipality) confirmed these differences: he mentioned a large number of fruit trees and shrubs, as well as chestnut-based recipes, found only in the Natisone Valleys (e.g., buje, a dessert based on chestnut and corn flour, raisins, and sugar boiled in water and eaten with cream).

\section{Differences between Slovenes and Friulians}

Almost $60 \%$ of the plants are common to the two communities. With regard to the differences, ecological unavailability plays a role: the Natisone Valleys and Torreano are in slightly different climatic zones and at different altitudes. For instance, some conifers such as Abies, Pinus, and Larix do not grow in Torreano because of the lower altitude. Differences between the two communities may also depend on cultural saliency, as is the case for Aloysia citriodora 
This is the postprint version of the article:

Mattalia, G., Soukand, R., Corvo, P., \& Pieroni, A. (2020 Dissymmetry at the Border: Wild Food and Medicinal Ethnobotany of Slovenes and Friulians in Northeast Italy Economic Botany, 10.1007/s12231-020-09488-y.

Palau, Sempervivum tectorum L., Sanguisorba minor Scop., Solanum dulcamara L., and Sonchus oleraceus (L.) L.

Yet, wild fruits like apples, pears, cherries, and plums are ecologically available in both areas, but are culturally important only in the Natisone Valleys, which are in a more remote area and thus Nediško speakers need to use more local resources.

We also confirmed that cultural differences play a role in the way the gathered taxa are used: litùn is not prepared in the Natisone Valleys whereas marve are not prepared in Torreano. Due to a shared environment, ingredients are common, but the cultural and geographical isolation of the Nediško speakers shaped diverse gastronomic preferences.

Figure 4 illustrates the overlap of the different recipes in which wild leafy vegetables are used. In the Nediško area 11 taxa are used, while Friulian speakers use a larger variety of plants, including up to 41 different taxa. Only five taxa are common to three different recipes (štakanje, litùn, and Torreano omelets), while all of the taxa used to make marve are also used in Torreano omelets. 

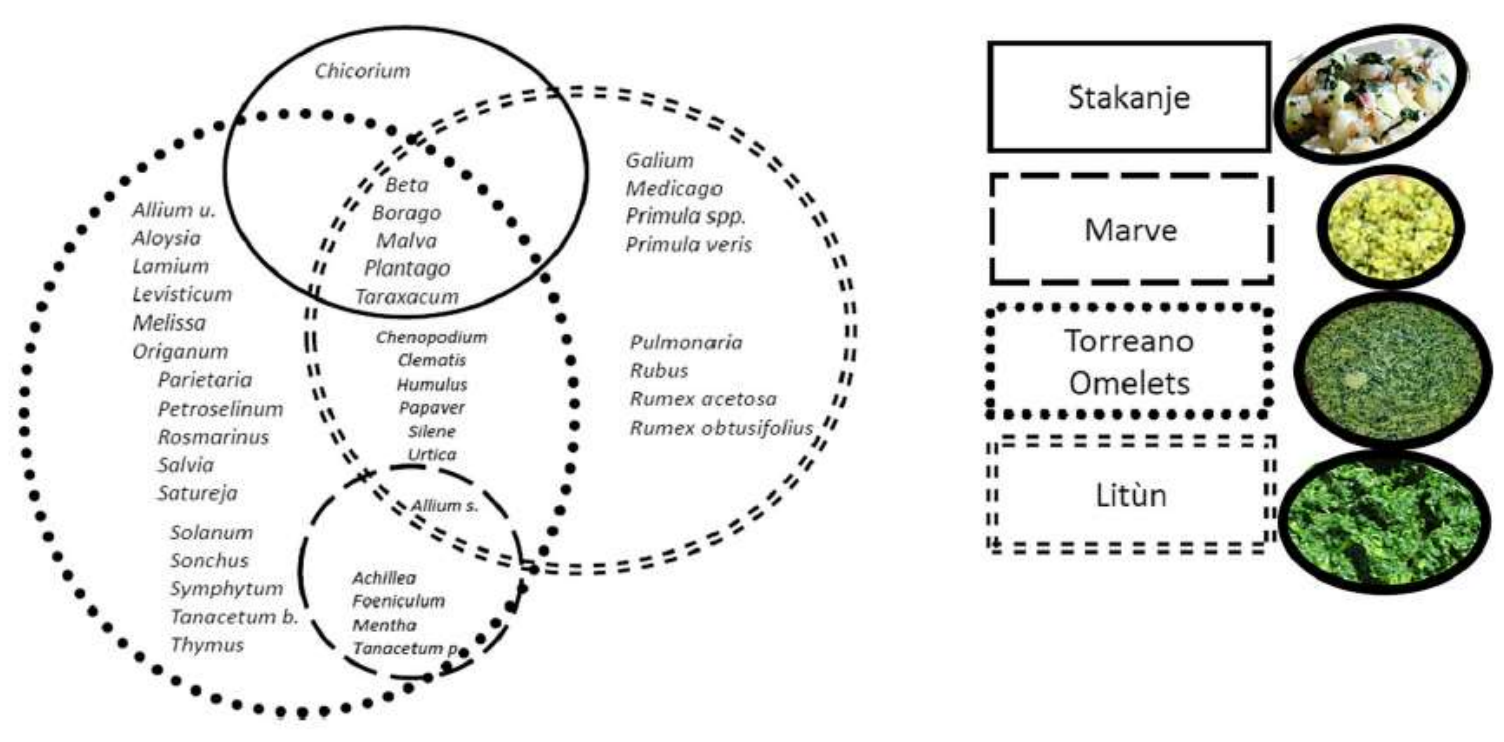

Fig. 4. Plant taxa used in the most popular food preparations among Nediško speakers (štakanje and marve) and Friulian speakers (Torreano omelets and litùn).

Preparations with Wild Plant Ingredients

Mixtures of wild and semi-domesticated food plants are common preparations in Italy, although with many variances and preparations such as boiled, in soups, and in salads (Guarrera and Savo 2016). Taste is an important variable, and the quantity and quality of ingredients vary from family to family. However, these mixtures not only are rich in bioactive compounds, minerals, and fiber, but they also express the richness and diversity of their gastronomic heritage. In recent times, wild plants have increased in popularity and more and more people now consider wild plants as healthy ingredients. Therefore, special attention was given to the documentation of the components of four traditional food recipes, which in quite recent history, according to Paoletti et al. (1995), contained dozens of wild and semi-domesticated ingredients. Litùn is a mixture of wild plants that are rinsed, boiled, and then stir-fried in a pan with olive oil, butter, or pork fat. In other areas of Friuli, this dish is also known by the names lidùn, pistic, and frita (Paoletti et al. 
This is the postprint version of the article:

Mattalia, G., Soukand, R., Corvo, P., \& Pieroni, A. (2020 Dissymmetry at the Border: Wild Food and Medicinal Ethnobotany of Slovenes and Friulians in Northeast Italy Economic Botany, 10.1007/s12231-020-09488-y.

1995). Torreano omelet, literally frittata con le erbe ("Omelet with wild herbaceous plants"), consists of more than 20 different plants. Its preparation includes a few ingredients in addition to wild and semi-domesticated plants (eggs and milk if available). Some of these plants can be cultivated in vegetable gardens or close to the house, while others have to be harvested in other habitats and sometimes at other altitudes. In the Natisone Valleys frittata con le erbe is also common, but there is also another identarian recipe called marve, which in Nediško means crumbs. In fact, the ingredients (a mix of wild and semi-domesticated plants, milk, and eggs) are cooked together and served in cups as crumbles. Another recipe is štakanje whose main ingredients are potatoes, turnip leaves or other semi-domesticated plants such as Borago or Beta vulgaris L., and lard. Potatoes are cooked with the leaves and then pressed to obtain a puree, then stir-fried lard is added and the dish is served with some ripe cheese.

\section{Grappa: A Crucial Slovenian Cultural Marker}

Grappa is considered an important food/medicine in both Friulian and Nediško areas, and it can be prepared with more than 40 different taxa, which are often added when they are available in nature. Grappa has several functions as a medicinal ingredient in both topical and oral applications ("it is a universal medicine"), as a social and recreational beverage, and as a food (especially fruit) preservative.

We found six shared medicinal taxa used both as oral applications (Artemisia spp., Ruta graveolens L., Salvia officinalis L.) and as ointments obtained from plant maceration in grappa (Arnica montana L., Gentiana lutea L., Juniperus communis L.). As early as 1884, Carlo Podrecca reported the importance of grappa as it was "the only medicine" for the inhabitants of the Natisone 
This is the postprint version of the article:

Mattalia, G., Soukand, R., Corvo, P., \& Pieroni, A. (2020 Dissymmetry at the Border: Wild Food and Medicinal Ethnobotany of Slovenes and Friulians in Northeast Italy Economic Botany, 10.1007/s12231-020-09488-y.

Valleys. In addition, 10 taxa for recreational grappa were found in common. Most of the taxa were used as ingredients for recreational grappa (which in the Italian tradition is not only a social beverage but also a digestive). However, in some cases, grappa is used as a preservative for fruits; for example, Vaccinium myrtillus, Prunus spp., Fragaria vesca L., and Ziziphus jujuba Mill. One Friulian interviewee reported an old recipe called Pentolaccia russa-big Russian pot—in which fruits, when ripe, were preserved in grappa for wintertime.

Grappa is perceived as being more a specialty of the Natisone Valleys. The importance of grappa for the Slovenian speaking population was confirmed by the Slovenian speaker interviewed close to Torreano as he said that grappa "is a universal medicine, if made from good stuff." He also highlighted the importance of Juniperus communis and Arnica montana in making grappa and extracting the oil to treat abdominal and joint pain.

Medicinal uses of plants infused in grappa have also been documented in Slovenia by Lumpert and Kreft (2017). Among the taxa used for recreational grappa, Gentiana lutea was also reported in the Swiss Alps (Abbet et al. 2014), and Artemisia absinthium L. is common all over the Alpine arc and in some areas of central Italy (Pieroni 2000). The extremely popular custom of macerating various plants in alcohol/grappa is widespread in Slavic areas and bordering regions (see for example Sõukand and Kalle 2013 and Pieroni and Sõukand 2018). These alcoholic homemade preparations often retain the characteristics of real food-medicines, i.e., beverages thatsimilarly to some homemade plant teas_-are often drunk for recreational purposes and at the same time with the aim of improving health or even treating actual diseases (Pieroni 2000). 
This is the postprint version of the article:

Mattalia, G., Soukand, R., Corvo, P., \& Pieroni, A. (2020 Dissymmetry at the Border: Wild Food and Medicinal Ethnobotany of Slovenes and Friulians in Northeast Italy Economic Botany, 10.1007/s12231-020-09488-y.

The Importance of Contact with Nature

Our interviewees reported that the tradition of gathering from the wild is still alive in this area. Despite the decrease of traditional ecological practices all over Europe, this area has not yet completely lost the connection with the "wild." The recipes described above confirm that there is a strong connection between biodiversity in the field and diversity in culinary dishes. Particularly in springtime, most of the informants harvest plants that are later prepared, dried (e.g., flowers and inflorescences of Tilia cordata Mill., Malva sylvestris, Sambucus nigra, and Foeniculum vulgare), or frozen (especially green leaves). Landscapes have changed over the last 60 years and many informants deplore forest expansion ("Oh raspberries! They used to grow in the second year after a forest clearing; now the forest is uncontrolled and raspberries are hard to find."). After WWII, when many men left for Belgium, women were left to take care of the family, and cultivate small vegetable gardens and gather plants from the wild both for medicinal and food purposes ("There was no money, and sometimes we sneaked out to follow some elder women and learn where to harvest useful plants.”). At the beginning of the 1990s, Paoletti et al. (1995) reported 56 taxa used for making the litùn, whereas now we only recorded 18 taxa (plus four not identified) for the same recipe. However, despite this "simplification" (which may be due to the availability of other resources), local women still harvest many wild plants as they know the specific time and location to gather these taxa as well as their preparation. The loss of habitat is not always an obstacle to continued harvesting; for example, Lactuca alpina (L.) A.Gray was reported to be common in the study areas until the 1960s. Later it diminished and now it is gathered only in other areas of Friuli Venezia Giulia, such as Carnia. Some informants reported traveling to Carnia every year to gather this plant. 
This is the postprint version of the article:

Mattalia, G., Soukand, R., Corvo, P., \& Pieroni, A. (2020 Dissymmetry at the Border: Wild Food and Medicinal Ethnobotany of Slovenes and Friulians in Northeast Italy Economic Botany, 10.1007/s12231-020-09488-y.

Traditional recipes are crucial for maintaining not only identity and traditional ecological knowledge but also biodiversity. Local inhabitants bring a great diversity of plant foods to their table every day. This aptitude has resulted in an initiative in which local restaurants offer spring and autumn menus based on local fresh (often wild) ingredients and traditional recipes (the initiative is called "Invito a pranzo" [literally: Invitation to lunch] and around 20 restaurants of the Natisone Valleys currently participate), attracting people from more urbanized areas and contributing to the revival of "peasant ingredients" for haute-cuisine.

The Sacred Natural Site of Castelmonte: A Key Place Shaping Biocultural Identity?

Many interviewees mentioned the sacred natural site of Castelmonte, especially in the villages of the Natisone Valleys. Indeed, the Shrine of Castelmonte has an important cultural salience particularly for Nediško speakers, but we could not find any evidence of the influence of this shrine on the local traditional knowledge. This may be due to a century-long lack of management by a settled community of monks (Mattalia et al. 2019). Before 1913, when the current community of capuchin friars was established, the shrine was managed by one or two priests of different origins (Italian, Slovenian, Friulian, etc.) and there is no evidence of their involvement in any food or medicinal production. Moreover, as the Natisone Valleys were sparsely populated, each small community used to have a small chapel and a priest that was shared with other communities, and thus the main religious rituals were carried out within the village. However, especially in case of exceptional events, such as droughts, pilgrimages were organized to the sacred natural site of Castelmonte (Gariup et al. 1994). The Frulian interviewees also 
This is the postprint version of the article:

Mattalia, G., Soukand, R., Corvo, P., \& Pieroni, A. (2020 Dissymmetry at the Border: Wild Food and Medicinal Ethnobotany of Slovenes and Friulians in Northeast Italy Economic Botany, 10.1007/s12231-020-09488-y.

reported some pilgrimages to this shrine, particularly in commemoration of the earthquake that struck the area in 1976.

Central and Eastern European Plant Uses at the Fringe of Western Europe

Due to its location at a crossroads, Friuli Venezia Giulia has adopted some Central and Eastern European plant uses. While there is no evidence of the use of birch sap (Betula spp.) in Italy, its use is very popular in Eastern Europe and it was recorded in Slovenia, indicating an “imported" use by the Nediško speakers who mentioned it (Svanberg et al. 2012). Rheum spp. is an important plant in Germanic cultures and was reported as a food plant in Ukraine (Sõukand and Pieroni 2016) where it is locally perceived as a plant coming from the "East." Sempervivum tectorum was mainly mentioned in the Nediško language in the Natisone Valleys. It is used to treat earache by applying its juice directly into the ear canal. This use was also found in Eastern (Papp et al. 2013) and Southeastern Europe (Mustafa et al. 2012; Pieroni 2017). Tussilago farfara L.is well-known in Eastern Europe to wrap sarma (Dogan et al. 2015; Łuczaj et al. 2015), but it is also used for recreational teas (in the Czech Republic, Pawera et al. 2017) and medicinal tinctures and infusions (in Ukraine and Russia, Stryamets et al. 2015). It is one of the plants listed in the Maria Treben bestseller Health through God's Pharmacy (Treben 1984) and this may have contributed to its popularity in Eastern Europe. In the current study, this plant was mentioned only in the Natisone Valleys. These uses, typically Eastern European, may underline the influence of Eastern cultures in Friuli Venezia Giulia and in particular the Natisone Valleys as a common-root language and culture facilitate it. 
This is the postprint version of the article:

Mattalia, G., Soukand, R., Corvo, P., \& Pieroni, A. (2020 Dissymmetry at the Border: Wild Food and Medicinal Ethnobotany of Slovenes and Friulians in Northeast Italy Economic Botany, 10.1007/s12231-020-09488-y.

Knowledge Transmission and the "Double Borders" of Nediško Speakers

Biocultural heritage is passed down along two different pathways in these two communities. In Torreano, a considerable number of inhabitants of the main village meet once or twice a week in the municipality social room to spend some time together. This recreational time is often seen as a moment to share new discoveries and recount old stories. It reinforces the sense of community and promotes knowledge exchange relating to recreational activities such as mushroom harvesting, litùn variants, and grappa tasting.

In the Natisone Valleys, the borders play a crucial role in shaping identities and forms of knowledge transmission. "The border became an inner dimension" (Cozzi 2009) as the inhabitants of the Natisone Valleys shared two borders: a cultural one with the Friulian inhabitants of the plain and a geographic one with Slavic Yugoslavia for 60 years. During our research, the Nediško speakers showed a strong sense of community (see also Šiškovič 1978), and associationism is widely practiced. For instance, Rečan Aldo Klodič, a local cultural association, makes a yearly calendar highlighting important Nediško events, as well as presenting month by month several pictures of local interest such as local flowers, local people, small settlements, and old tools. In addition, local magazines (including parish bulletins) and multilingual newspapers publish content related to aspects of local life. These online and printed documents in Nediško, as well as a bilingual school (Italian/Slovenian), contribute to creating a strong sense of community and easing the process of intergeneration and the exchange of local knowledge in general.

Therefore, it is important to understand the mechanisms through which language and cultural identity are maintained among minorities as these play a crucial role in keeping, possibly changing, and shaping TEK. Iniesta-Arandia et al. (2014) pointed out the fact that the maintenance 
This is the postprint version of the article:

Mattalia, G., Soukand, R., Corvo, P., \& Pieroni, A. (2020 Dissymmetry at the Border: Wild Food and Medicinal Ethnobotany of Slovenes and Friulians in Northeast Italy Economic Botany, 10.1007/s12231-020-09488-y.

of ecological knowledge, transmitted at both the family and community level, greatly depends on the time spent in the area. Indeed, we can observe that the geographical isolation and the historical scarcity of job opportunities in the Natisone Valleys contributed to limiting the immigration process, while fostering emigration. Therefore, we found that in the Natisone Valleys the body of knowledge was more consistent than in Torreano, where proximity to the town of Cividale and its position in the plain have contributed to greater migratory flows, both incoming and outgoing. However, other factors affecting the erosion of TEK in both the communities include the abandonment of agricultural activities, which has impacted the application of local traditional knowledge through direct experience, and the number of people receiving a university education, which has prompted local young people to live in bigger cities and thus, in most cases, interrupting the transmission of TEK between generations.

Moreover, the spatial distribution and changes of TEK related to plants in border areas also depend on national and local cultural and political factors, how they possibly influence negotiations between minority and dominant groups, and especially how these factors balance or disrupt the fragile equilibrium between "centripetal" acculturation streams and "centrifugal" cultural identity-driven regionalist or even nationalist tendencies.

\section{Dissymmetry at the Border}

The borders analyzed in this case study play a crucial role in reinforcing cultural identity, and thus increasing the cultural distance between the two linguistic communities of Friulian and Nediško speakers. 
This is the postprint version of the article:

Mattalia, G., Soukand, R., Corvo, P., \& Pieroni, A. (2020 Dissymmetry at the Border: Wild Food and Medicinal Ethnobotany of Slovenes and Friulians in Northeast Italy Economic Botany, 10.1007/s12231-020-09488-y.

The historical background includes important features that lead to an important dissymmetry at the border. Nediško speakers are linguistically and culturally Slavic, but politically Italian or, more precisely, Venetian. Indeed, during the time of the Republic of Venice, populations living in the Natisone Valleys were considered "very faithful," and their cultural and linguistic diversity was accepted in order to protect the borders and to ease trading, which was an important characteristic of the republic. As Melik (1978) pointed out, the Nediško speakers "who received some formal education belonged with heart and brain to Italy from a political and institutional perspective and to Slovenia from a linguistic and national perspective." Therefore, Nediško speakers had two strong cultural roots: a sense of belonging to the Slavic world and a sense of political belonging, and the attendant protection, to the powerful Republic of Venice, which later played an important role in joining the newly established Republic of Italy (1866). On the contrary, the cultural history of Friulians consists of important cities, expressions of "Friulianess," such as Aquileia and Cividale, but also of subjugation to the Republic of Venice and the common root of the Friulian and Venetian languages that made Friulians easier to assimilate. These processes made the cultural identity of Friulian speakers (living in the Torreano area) less distinct than that of Nediško speakers. This unbalanced historical and cultural background caused a dissymmetry that has resulted in a lower consistency of the most-used plants and, in general, a lower level of biocultural diversity.

\section{Conclusions}

This research conducted in Friuli Venezia Giulia provides insights into ethnobotanical knowledge in the context of linguistic minorities and borders and explores the influence of cultural 
This is the postprint version of the article:

Mattalia, G., Soukand, R., Corvo, P., \& Pieroni, A. (2020 Dissymmetry at the Border: Wild Food and Medicinal Ethnobotany of Slovenes and Friulians in Northeast Italy Economic Botany, 10.1007/s12231-020-09488-y.

and geographic isolation. Torreano and the Natisone Valleys are rural areas where people are still connected to nature and knowledge about plants is still important in their daily lives. The high Jaccard Similarity Index for wild and semi-domesticated taxa indicates a common ecological landscape, while food and medicinal uses present remarkable differences between the two communities. Indeed, the same plants were often used in different recipes, which represent an expression of distinct identities, due in part to "the inner border" and its embedded geographic and cultural isolation of the Nediško speakers. Moreover, in the Natisone Valleys there is greater consistency of the most-used plants, and many Eastern European uses were recorded. Therefore, despite social and economic shifts, the inhabitants of the villages of the Natisone Valleys appear to be endowed with a great resilience of the most common traditional ecological knowledge, practices, and beliefs. Strengthened in century-long contact with "otherness"-Friulians, Italians, or the Habsburg Empire-while living beyond cultural or geographic borders, the cultural identity of the Nediško speakers has been a fundamental resource for the survival of their language, values, and communities.

Although our set of data is rather restricted and does not allow in-depth statistical analyses and definitive conclusions, we suggest that culture and language, together with ecological availability of the species, play a vital role in preserving biocultural identity at the community level. Moreover, we found an important dissymmetry shaped by the different distances of the two groups to the dominant standard Venetian (and later Italian) mainstream and this may have strongly affected how cultural identity was built in relation to the dominant cultural code. Future studies should address which strategies local communities have adopted for fostering the resilience of their plant cultural heritage, as this may be crucial for transboundary research projects aimed to 
This is the postprint version of the article:

Mattalia, G., Soukand, R., Corvo, P., \& Pieroni, A. (2020 Dissymmetry at the Border: Wild Food and Medicinal Ethnobotany of Slovenes and Friulians in Northeast Italy Economic Botany, 10.1007/s12231-020-09488-y.

identify these main factors in order to concretely contribute to the dynamic preservation of ethnobotanical diversity in the European context.

\section{Acknowledgments}

Special thanks go to all the study participants who generously shared their TEK regarding plants. This research was funded by the Italian Ministry of Education, Universities and Research through the PRIN project 'Biodiversity and ecosystem services in Sacred Natural Sites (BIOESSaNS)', Nr. 2015P8524C, as well as from the University of Gastronomic Sciences of Pollenzo, Italy.

\section{Literature Cited}

Abbet, C., R. Mayor, D. Roguet, R. Spichiger, M. Hamburger, and O. Potterat. 2014. Ethnobotanical survey on wild alpine food plants in Lower and Central Valais (Switzerland). Journal of Ethnopharmacology 151(1):624-634.

Appi, E., R. Appi, A. Pagnucco, and D. Pagnucco. 1979. Le piante nell'uso popolare in Friuli: terapia e cucina. Pordenone: Edizioni Concordia Sette.

ARPA FVG. 2014. "Il clima del Friuli Venezia Giulia." 2014. http://www.meteo.fvg.it/clima/clima_fvg/02_documenti_descrittivi_e_approfondimenti/0 1_Il_clima_del_Friuli_Venezia_Giulia/clima_fvg-divulgativo.pdf (2 February 2019).

Augé, M. 1992. Non-Lieux. Introduction a 'une anthropologie de la surmodernite.' Paris: Le Seuil. Bonessa, E. 2013. L'infinita polemica, Carlo Podrecca e la Slavia Italiana. Udine: Aviani \& Aviani Editori. 
This is the postprint version of the article:

Mattalia, G., Soukand, R., Corvo, P., \& Pieroni, A. (2020 Dissymmetry at the Border: Wild Food and Medicinal Ethnobotany of

Slovenes and Friulians in Northeast Italy Economic Botany, 10.1007/s12231-020-09488-y.

Ceuterick, M., I. Vandebroek, B. Torry, and A. Pieroni. 2008. Cross-cultural adaptation in urban ethnobotany: The Colombian folk pharmacopoeia in London. Journal of Ethnopharmacology 120(3):342-359.

Christanell, A., B. Vogl-Lukasser, C. R. Vogl, and M. Gütler. 2010. The cultural significance of wild gathered plant species in Kartitsch (Eastern Tyrol, Austria) and the influence of socioeconomic changes on local gathering practices. In: Ethnobotany in the new Europe: people, health, and wild plant resources, R. Puri and A. Pieroni, eds., 51-75. New York: Berghahn Books.

Coassini-Lokar, L., L. Poldini, and G. Angeloni Rossi. 1983. Appunti di etnobotanica del FriuliVenezia Giulia. Gortania-Atti del Museo Friuliano di Storia Naturale 4:101-152.

Costantini, G. 1941. Litún o lidún: erbucce primaverili mangerecce nella tradizione popolare Friuliana. Lares 12(3):210-215.

Cozzi, D. 2009. "The Inner Frontier." Borders, Narratives, and Cultural Intimacy in Topolò/Topolove; “Notranja Meja.” Meje, Pripovedi In Kulturna Intimnost V Topolovem. Traditiones 38(2):151-164.

Dogan, Y., A. Nedelcheva, Ł. Łuczaj, C. Drăgulescu, G. Stefkov, A. Maglajlić, J. Ferrier, N. Papp, B. Mustafa, Z. Dajić-Stevanović, and A. Pieroni. 2015. Of the importance of a leaf: The ethnobotany of sarma in Turkey and the Balkans. Journal of Ethnobiology and Ethnomedicine 11(1):26.

Frascaroli, F., S. Bhagwat, R. Guarino, A. Chiarucci, and B. Schmid. 2016. Shrines in Central Italy conserve plant diversity and large trees. Ambio 45(4):468-479. 
This is the postprint version of the article:

Mattalia, G., Soukand, R., Corvo, P., \& Pieroni, A. (2020 Dissymmetry at the Border: Wild Food and Medicinal Ethnobotany of Slovenes and Friulians in Northeast Italy Economic Botany, 10.1007/s12231-020-09488-y.

and B. Verschuuren. 2016. Linking biocultural diversity and sacred sites: Evidence and recommendations in the European framework. In: Biocultural Diversity in Europe, M. Agnoletti and F. Emanueli, eds., 389-417. New York: Springer.

Gariup, M., R. Gariup, and R. Rucli. 1994. Topolove. Pripoved o koreninah beneške vasi / Topolò. Racconto sulle origini di un paese delle Valli del Natisone. San Pietro al Natisone, Italy: Circolo Culturale Rečan.

González-Tejero, M. R., M. Casares-Porcel, C. P. Sánchez-Rojas, J. M. Ramiro-Gutiérrez, J. Molero-Mesa, A. Pieroni, M. E. Giusti, E. Censorii, C. de Pasquale, A. Della, D. Paraskeva-Hadijchambi, A. Hadjichambis, Z. Houmani, M. El-Demerdash, M. El-Zayat, M. Hmamouchi, and S. Eljohrig. 2008. Medicinal plants in the Mediterranean area: Synthesis of the results of the project Rubia. Journal of Ethnopharmacology 116(2):341357.

Guarrera, P. M. and V. Savo. 2016. Wild food plants used in traditional vegetable mixtures in Italy. Journal of Ethnopharmacology 185:202-234.

Iniesta-Arandia, I., D. G. del Amo, A. P. García-Nieto, C. Piñeiro, C. Montes, and B. MartínLópez. 2014. Factors influencing local ecological knowledge maintenance in Mediterranean watersheds: Insights for environmental policies. Ambio 44(4):285-296.

ISE 2008. The ISE Code of Ethics. http://www.ethnobiology.net/what-we-do/core-programs/iseethics-program/code-of-ethics/ (05 December 2018).

International Society of Ethnobiology. 2008. International Society of Ethnobiology Code of Ethics. http://ethnobiology.net/code-of-ethics/ (05 December 2018). 
This is the postprint version of the article:

Mattalia, G., Soukand, R., Corvo, P., \& Pieroni, A. (2020 Dissymmetry at the Border: Wild Food and Medicinal Ethnobotany of Slovenes and Friulians in Northeast Italy Economic Botany, 10.1007/s12231-020-09488-y.

Łuczaj, Ł., K. Stawarczyk, T. Kosiek, M. Pietras, and A. Kujawa. 2015. Wild food plants and fungi used by Ukrainians in the western part of the Maramureş region in Romania. Acta Societatis Botanicorum Poloniae 84(3):339-346.

Lumpert, M. and S. Kreft. 2017. Folk use of medicinal plants in Karst and Gorjanci, Slovenia. Journal of Ethnobiology and Ethnomedicine 13(1):16.

Maffi, L. 2005. Linguistic, cultural and biological diversity. Annual Review of Anthropology 29:599-617.

Marsico, G. 2016. The borderland. Culture \& Psychology 22(2):206-215.

Mattalia, G., R. Sõukand, P. Corvo, A. Pieroni. 2019. Scholarly vs. traditional knowledge: Effects of sacred natural sites on ethnobotanical practices in Tuscany, Central Italy. Human Ecology 1-15.

Maxia, A., M. C. Lancioni, A. N. Balia, R. Alborghetti, A. Pieroni, and M. C. Loi. 2008. Medical ethnobotany of the Tabarkins, a Northern Italian (Ligurian) minority in south-western Sardinia. Genetic Resources and Crop Evolution 55(6):911-924.

Melik V. 1978. Gli Sloveni della Benecìa 1797-1866. In: La storia della Slavia Italiana, Centro Studi Nediža, 77-89. Trieste: Edito

Menendez-Baceta, G., L. Aceituno-Mata, V. Reyes-García, J. Tardío, M. Salpeteur, and M. Pardo-de-Santayana. 2015. The importance of cultural factors in the distribution of medicinal plant knowledge: A case study in four Basque regions. Journal of Ethnopharmacology 161:116-127. 
This is the postprint version of the article:

Mattalia, G., Soukand, R., Corvo, P., \& Pieroni, A. (2020 Dissymmetry at the Border: Wild Food and Medicinal Ethnobotany of Slovenes and Friulians in Northeast Italy Economic Botany, 10.1007/s12231-020-09488-y.

Mustafa, B., A. Hajdari, F. Krasniqi, E. Hoxha, H. Ademi, C. L. Quave, and A. Pieroni. 2012. Medical ethnobotany of the Albanian Alps in Kosovo. Journal of Ethnobiology and Ethnomedicine 8(1):6.

Oman, A. 1992. Etnobotanica della Val Canale: con particolare riguardo ai fitonimi sloveni di Ugovizza, Valbruna, Camporosso e S. Leopoldo. Cividale del Friuli: Società Cooperativa Editrice DOM.Ostermann, V. 1978. La vita in Friuli: usi, costumi e credenze popolari. Udine: Del Bianco Editore.

Paoletti, M. G., A. L. Dreon, and G. G. Lorenzoni. 1995. Pistic, traditional food from western Friuli, N.E. Italy. Economic Botany 49(1):26-30.

Papp, N., K. Birkás-Frendl, Á. Farkas, and A. Pieroni. 2013. An ethnobotanical study on homegardens in a Transylvanian Hungarian Csángó village (Romania). Genetic Resources and Crop Evolution 60(4):1423-1432.

Pawera, L., Ł. Łuczaj, A. Pieroni, and Z. Polesny. 2017. Traditional plant knowledge in the White Carpathians: Ethnobotany of wild food plants and crop wild relatives in the Czech Republic. Human Ecology 45(5):655-671.

Pieroni, A. 2000. Medicinal plants and food medicines in the folk traditions of the upper Lucca Province, Italy. Journal of Ethnopharmacology, 70(3): 235-273.

. 2017. Traditional uses if wild food plants, medicinal plants, and domestic remedies in Albanian, Aromanian and Macedonian villages in South-Eastern Albania. Journal of Herbal Medicine 9:81-90. 
This is the postprint version of the article:

Mattalia, G., Soukand, R., Corvo, P., \& Pieroni, A. (2020 Dissymmetry at the Border: Wild Food and Medicinal Ethnobotany of Slovenes and Friulians in Northeast Italy Economic Botany, 10.1007/s12231-020-09488-y.

and C. L. Quave. 2005. Traditional pharmacopoeias and medicines among Albanians and Italians in Southern Italy: A comparison. Journal of Ethnopharmacology 101:258-270. and R. Sõukand. 2017. Are borders more important than geographical distance? The wild food ethnobotany of the Boykos and its overlap with that of the Bukovinian Hutsuls in Western Ukraine. Journal of Ethnobiology 37(2):326-345.

and R. Sõukand. 2018. Forest as stronghold of local ecological practice: Currently used wild food plants in Polesia, Northern Ukraine. Economic Botany 72(3):311-331.

, H. Zaman, S. Ayub, and B. Torry. 2010. My doctor doesn't understand why I use them. Herbal and Food Medicines Amongst the Bangladeshi Community in West Yorkshire, UK. In: Ethnobotany in the new Europe: People, health, and wild plant resources, eds., R. Puri and A. Pieroni, 112-146. New York: Berghahn Books.

Pignatti, S. 1982. Flora d'Italia. Bologna: Edagricole.

Pike, K. L. 1967. Etic and emic standpoints for the description of behavior. In: Language in relation to a unified theory of the structure of human behavior, ed., K. L. Pike, 37-72. The Hague, Netherlands: Mouton \& Co.

Podrecca, C. 1884. Slavia Italiana. Cividale del Friuli: Fulvio Giovanni Tipografo Editore.

Schunko, C. and C. R. Vogl. 2010. Organic farmers use of wild food plants and fungi in a hilly area in Styria (Austria). Journal of Ethnobiology and Ethnomedicine 6(1):17.

Šiškovič, K. 1978. La Slavia dal 1866 al 1918. In: La storia della Slavia Italiana. Centro Studi Nediža, 61-76. Trieste: Editoriale Stampa Triestina. 
This is the postprint version of the article:

Mattalia, G., Soukand, R., Corvo, P., \& Pieroni, A. (2020 Dissymmetry at the Border: Wild Food and Medicinal Ethnobotany of Slovenes and Friulians in Northeast Italy Economic Botany, 10.1007/s12231-020-09488-y.

Sõukand, R. and R. Kalle. 2013. Where does the border lie: Locally grown plants used for making tea for recreation and/or healing, 1970s-1990s Estonia. Journal of Ethnopharmacology 150(1):162-174.

and A. Pieroni. 2016. The importance of a border: Medical, veterinary, and wild food ethnobotany of the Hutsuls living on the Romanian and Ukrainian sides of Bukovina. Journal of Ethnopharmacology 185:17-40.

C. L. Quave, A. Pieroni, M. Pardo-de-Santayana, J. Tardío, R. Kalle, Ł. Łuczaj, I. Svanberg, V. Kolosova, L. Aceituno-Mata, G. Menendez-Baceta, I. KołodziejskaDegórska, E. Pirożnikow, R. Petkevičius, A. Hajdari, and B. Mustafa. 2013. Plants used for making recreational tea in Europe: A review based on specific research sites. Journal of Ethnobiology and Ethnomedicine 9(1):58.

Stevens, P. F. 2015. Angiosperm Phylogeny Website, version 14. http://www.mobot.org/MOBOT/research/APweb/ (6 February 2019).

Stryamets, N., M. Elbakidze, M. Ceuterick, P. Angelstam, and R. Axelsson. 2015. From economic survival to recreation: Contemporary uses of wild food and medicine in rural Sweden, Ukraine and NW Russia. Journal of Ethnobiology and Ethnomedicine 11(1):53.

Svanberg, I., R. Sõukand, Ł. Łuczaj, R. Kalle, O. Zyryanova, A. Dénes, N. Papp, A. Nedelcheva, D. Šeškauskaitè, I. Kołodziejska-Degórska, and V. Kolosova. 2012. Uses of tree saps in northern and eastern parts of Europe. Acta Societatis Botanicorum Poloniae 81(4).

The Plant List database 2013.

Toso, F. 2008. Le minoranze linguistiche in Italia. Bologna: Soc. Ed. Il Mulino.

Treben, M. 1984. Health Through God's Pharmacy. Steyr, Austria: Wilhelm Ennsthaler. 
This is the postprint version of the article:

Mattalia, G., Soukand, R., Corvo, P., \& Pieroni, A. (2020 Dissymmetry at the Border: Wild Food and Medicinal Ethnobotany of Slovenes and Friulians in Northeast Italy Economic Botany, 10.1007/s12231-020-09488-y.

Tutin T., V. Heywood, N. Burges, D. Valentine, S. Walters, D. Webb. 1964. Flora Europaea. Cambridge, United Kingdom: Cambridge University Press.

Verschuuren, B. 2012. Arguments for developing biocultural conservation approaches for sacred natural sites. In: Sacred Natural Sites, B. Verschuuren, R. Wild, J. Mcneely, and G. Oviedo, eds., 88-98. London: Routledge.

Wild, R. and C. McLeod. 2008. Sacred natural sites. Guidelines for Protected Area Managers. Gland, Switzerland: IUCN.

Taxa used for food and medicinal purposes recorded in Torreano $(n=16)$ and the Natisone Valleys $(n=15) . F=$ Friulians of Torreano; $N=$ Nediško speakers of the Natisone Valleys. The symbol * indicates a past use. (Grappa is an Italian schnapps while litùn, marve, and štakanje are local food preparations). Identification of incomplete voucher specimens was based on local nomenclature, as well as plant and habitat descriptions.

\begin{tabular}{|c|c|c|c|c|c|c|c|}
\hline \multirow{2}{*}{$\begin{array}{l}\text { Botanical taxon and } \\
\text { family }\end{array}$} & \multirow{2}{*}{$\begin{array}{l}\text { Recorded local } \\
\text { name }\end{array}$} & \multicolumn{2}{|c|}{$\begin{array}{l}\text { Number of } \\
\text { informants }\end{array}$} & \multirow{2}{*}{$\begin{array}{l}\text { Parts } \\
\text { used }\end{array}$} & \multirow{2}{*}{$\begin{array}{l}\text { Food use }(F) \text { or medicinal } \\
\text { use }(M)\end{array}$} & \multirow{2}{*}{$\begin{array}{l}\text { Torreano } \\
\text { (Friulians) } \\
\mathrm{n}=16\end{array}$} & \multirow{2}{*}{$\begin{array}{l}\text { Natisone } \\
\text { (Nediško) } \\
\mathbf{n}=15\end{array}$} \\
\hline & & $\mathbf{F}$ & $\mathbf{N}$ & & & & \\
\hline $\begin{array}{l}\text { Abies alba Mill. } \\
\text { (Pinaceae) }\end{array}$ & Abete & 0 & 1 & Shoots & F: Infusion in grappa & & 1 \\
\hline \multirow{4}{*}{$\begin{array}{l}\text { Achillea millefolium } \mathrm{L} \text {. } \\
\text { (Asteraceae) }\end{array}$} & \multirow{4}{*}{$\begin{array}{l}\text { Achillea; Ozebar } \\
(\mathrm{N})\end{array}$} & 0 & 9 & \multirow{4}{*}{$\begin{array}{l}\text { Aerial } \\
\text { parts }\end{array}$} & F: Infusion in grappa & & 2 \\
\hline & & & & & F: Omelets & & 8 \\
\hline & & & & & F: Soups & & 1 \\
\hline & & & & & $\mathrm{F}$ : Marve & & 1 \\
\hline
\end{tabular}


This is the postprint version of the article:

Mattalia, G., Soukand, R., Corvo, P., \& Pieroni, A. (2020 Dissymmetry at the Border: Wild Food and Medicinal Ethnobotany of Slovenes and Friulians in Northeast Italy Economic Botany, 10.1007/s12231-020-09488-y.

\begin{tabular}{|c|c|c|c|c|c|c|c|}
\hline & & & & & $\begin{array}{l}\text { M: Infusion to treat } \\
\text { abdominal pain due to } \\
\text { menstruation }\end{array}$ & & 1 \\
\hline & & & & & $\begin{array}{l}\text { M: Infusion to treat } \\
\text { bronchitis and phlegm }\end{array}$ & & 2 \\
\hline $\begin{array}{l}\text { Allium spp. } \\
\text { (Amaryllidaceae) }\end{array}$ & $\begin{array}{l}\text { Aglio selvatico } \\
\text { Česnàk }(\mathrm{N})\end{array}$ & 2 & 0 & $\begin{array}{l}\text { Bulbs } \\
\text { and } \\
\text { Leaves }\end{array}$ & F: Preserved with olive oil & 2 & \\
\hline \multirow{6}{*}{$\begin{array}{l}\text { Allium schoenoprasum } \\
\text { L. (Amaryllidaceae) }\end{array}$} & \multirow{6}{*}{ Erba cipollina } & 10 & 6 & \multirow{6}{*}{$\begin{array}{l}\text { Aerial } \\
\text { parts }\end{array}$} & F: Battered fried & 1 & \\
\hline & & & & & F: Litùn & 3 & \\
\hline & & & & & F: Marve & & 1 \\
\hline & & & & & F: Raw in salads & & 1 \\
\hline & & & & & F: Pesto sauce & 5 & \\
\hline & & & & & F: Omelets & 10 & 4 \\
\hline \multirow{2}{*}{$\begin{array}{l}\text { Allium ursinum } \mathrm{L} . \\
\text { (Amaryllidaceae) }\end{array}$} & \multirow{2}{*}{ Aglio ursino } & 9 & 8 & \multirow{2}{*}{$\begin{array}{l}\text { Aerial } \\
\text { parts }\end{array}$} & F: Pesto sauce & 9 & 6 \\
\hline & & & & & F: Omelets & & 6 \\
\hline \multirow{4}{*}{$\begin{array}{l}\text { Aloysia citriodora Palau } \\
\text { (Verbenaceae) }\end{array}$} & \multirow{4}{*}{ Erba Luisa } & 6 & 0 & \multirow{3}{*}{ Leaves } & F: Infusion in grappa & 6 & \\
\hline & & & & & F: Recreational tea & 1 & \\
\hline & & & & & F: Omelets & 5 & \\
\hline & & & & Flowers & $\begin{array}{l}\text { M: Infusion (with honey) to } \\
\text { treat flu and cough }\end{array}$ & 6 & \\
\hline \multirow{2}{*}{$\begin{array}{l}\text { Anethum graveolens L. } \\
\text { (Apiaceae) }\end{array}$} & \multirow{2}{*}{ Aneto } & 1 & 0 & Flowers & F: Infusion in grappa & 1 & \\
\hline & & & & Seeds & F: Seasoning (bread) & 1 & \\
\hline \multirow{2}{*}{$\begin{array}{l}\text { Arbutus unedo L. } \\
\text { (Ericaceae) }\end{array}$} & \multirow{2}{*}{ Corbezzolo } & 1 & 0 & \multirow{2}{*}{ Fruits } & F: Raw as a snack & 1 & \\
\hline & & & & & F: Infusion in grappa & 1 & \\
\hline \multirow{2}{*}{$\begin{array}{l}\text { Arctium lappa L. } \\
\text { (Asteraceae) }\end{array}$} & \multirow{2}{*}{$\begin{array}{l}\text { Bardana, Torica } \\
\text { (N) }\end{array}$} & & & Roots & F: Soups & & 1 \\
\hline & & 2 & 0 & Leaves & $\begin{array}{l}\text { M: Locally applied to treat } \\
\text { abdominal pain }\end{array}$ & 2 & \\
\hline
\end{tabular}


This is the postprint version of the article:

Mattalia, G., Soukand, R., Corvo, P., \& Pieroni, A. (2020 Dissymmetry at the Border: Wild Food and Medicinal Ethnobotany of Slovenes and Friulians in Northeast Italy Economic Botany, 10.1007/s12231-020-09488-y.

\begin{tabular}{|c|c|c|c|c|c|c|c|}
\hline $\begin{array}{l}\text { Armoracia rusticana } \\
\text { P.Gaertn., B.Mey. \& } \\
\text { Scherb. (Brassicaceae) }\end{array}$ & Cren & 1 & 0 & Roots & F: Grated on ham & 1 & \\
\hline $\begin{array}{l}\text { Arnica montana L. } \\
\text { (Asteraceae) }\end{array}$ & Arnica, Arnika (N) & 1 & 6 & Flowers & $\begin{array}{l}\text { M: Infusion in grappa, the } \\
\text { ointment obtained is then } \\
\text { locally applied on the skin } \\
\text { to treat dermatitis }\end{array}$ & 1 & 6 \\
\hline \multirow{4}{*}{$\begin{array}{l}\text { Artemisia absinthium L. } \\
\text { (Asteraceae) }\end{array}$} & \multirow{4}{*}{ Assenzio, Pelìn (N) } & 8 & 13 & \multirow{4}{*}{$\begin{array}{l}\text { Aerial } \\
\text { parts }\end{array}$} & F: Liquor & 3 & 2 \\
\hline & & & & & $\begin{array}{l}\text { M: Infusion as anti- } \\
\text { helminthic* }\end{array}$ & 3 & \\
\hline & & & & & $\begin{array}{l}\text { M: Infusion in grappa as } \\
\text { digestive }\end{array}$ & 2 & 8 \\
\hline & & & & & $\begin{array}{l}\text { M: Chewed to treat } \\
\text { abdominal pain }\end{array}$ & & 3 \\
\hline \multirow{2}{*}{$\begin{array}{l}\text { Artemisia dracunculus } \\
\text { L. (Asteraceae) }\end{array}$} & \multirow{2}{*}{ Dragoncello } & 0 & 1 & \multirow{2}{*}{$\begin{array}{l}\text { Aerial } \\
\text { parts }\end{array}$} & F: Seasoning & & 1 \\
\hline & & & & & F: Infusion in grappa & & 1 \\
\hline $\begin{array}{l}\text { Artemisia maritima L. } \\
(\text { Asteraceae })^{*}\end{array}$ & Santonigo $(\mathrm{F})$ & 3 & 0 & Leaves & $\begin{array}{l}\text { M: Infusion as anti- } \\
\text { helminthic* }\end{array}$ & 3 & \\
\hline \multirow{6}{*}{$\begin{array}{l}\text { Asparagus acutifolius L. } \\
\text { (Asparagaceae) } \\
\text { UNISGFRI017 }\end{array}$} & \multirow{6}{*}{$\begin{array}{l}\text { Asparago; Sparks } \\
\text { di mont (F), Sparzi } \\
\text { (N) }\end{array}$} & 11 & 12 & \multirow{6}{*}{ Stems } & F: Boiled with eggs & 3 & 7 \\
\hline & & & & & F: Preserved with olive oil & 4 & \\
\hline & & & & & F: Soups & & 2 \\
\hline & & & & & F: Boiled and then in salads & 1 & 3 \\
\hline & & & & & F: Preserved with vinegar & & 1 \\
\hline & & & & & F: Omelets & 4 & 5 \\
\hline $\begin{array}{l}\text { Bellis perennis L. } \\
\text { (Asteraceae) }\end{array}$ & Margheritine & 0 & 1 & Leaves & F: Omelets & & 1 \\
\hline \multirow{2}{*}{$\begin{array}{l}\text { Beta vulgaris L. } \\
\text { (Amaranthaceae) }\end{array}$} & \multirow{2}{*}{$\begin{array}{l}\text { Bieta selvatica, } \\
\text { Bleda }(\mathrm{F})\end{array}$} & 9 & 1 & \multirow{2}{*}{$\begin{array}{l}\text { Aerial } \\
\text { parts }\end{array}$} & F: Omelets & 9 & \\
\hline & & & & & F: Štakanje & & 1 \\
\hline
\end{tabular}


This is the postprint version of the article:

Mattalia, G., Soukand, R., Corvo, P., \& Pieroni, A. (2020 Dissymmetry at the Border: Wild Food and Medicinal Ethnobotany of Slovenes and Friulians in Northeast Italy Economic Botany, 10.1007/s12231-020-09488-y.

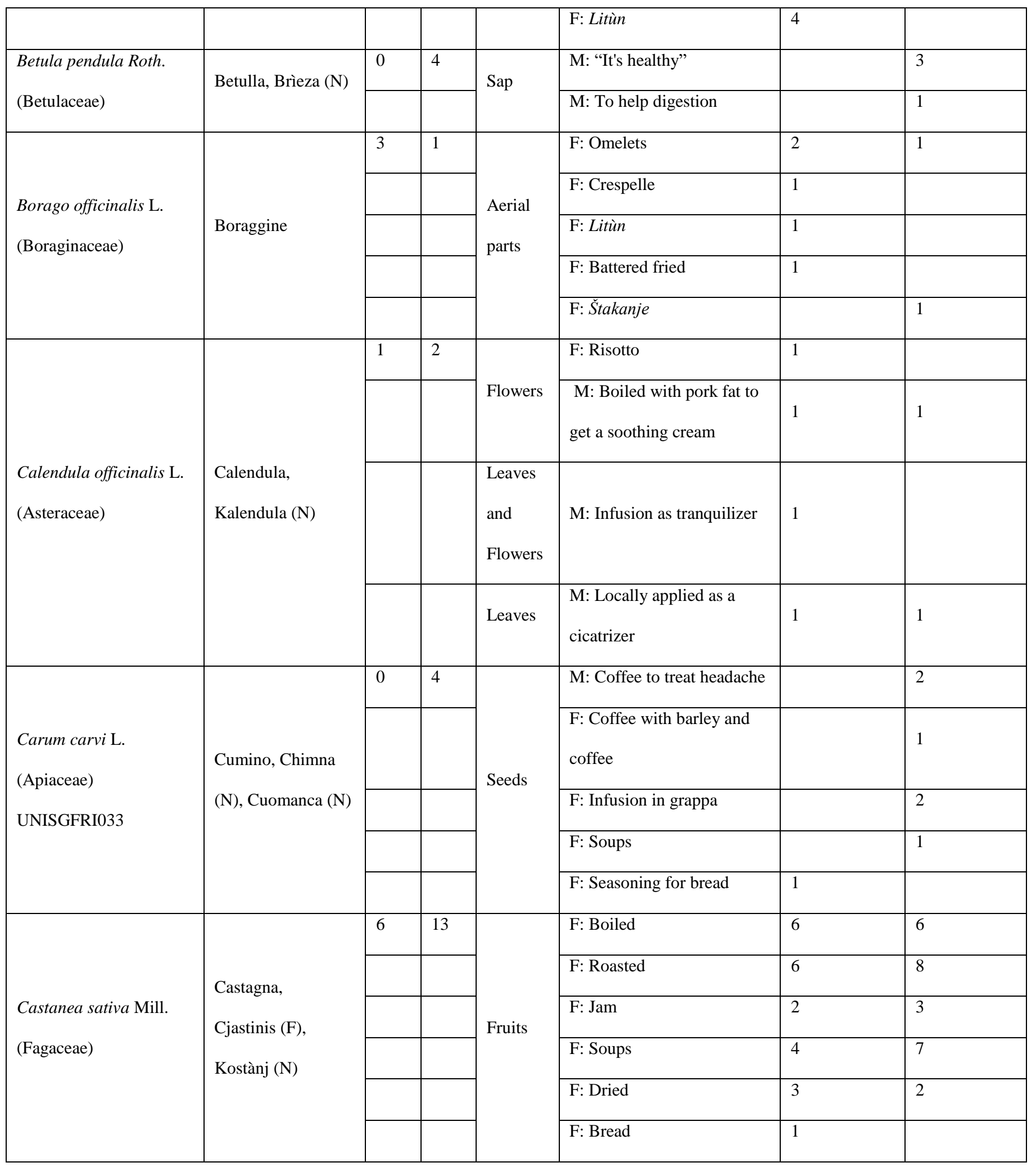


This is the postprint version of the article:

Mattalia, G., Soukand, R., Corvo, P., \& Pieroni, A. (2020 Dissymmetry at the Border: Wild Food and Medicinal Ethnobotany of Slovenes and Friulians in Northeast Italy Economic Botany, 10.1007/s12231-020-09488-y.

\begin{tabular}{|c|c|c|c|c|c|c|c|}
\hline & & & & & $\begin{array}{l}\text { F: Desserts (Gubane, } \\
\text { Strucchi) }\end{array}$ & & 1 \\
\hline & & & & & F: Infusion in grappa & & 2 \\
\hline & & & & & F: Gnocchi & & 1 \\
\hline & & & & Flowers & F: Infusion in grappa & 3 & \\
\hline $\begin{array}{l}\text { Centaurea spp. } \\
\text { (Asteraceae) }\end{array}$ & Centaurea & 0 & 1 & Leaves & $\begin{array}{l}\text { M: Infusion as digestive "It } \\
\text { cleans the stomach because } \\
\text { it is bitter" }\end{array}$ & & 1 \\
\hline Chelidonium majus L. & Celidonia, Skrabula & 1 & 7 & & $\begin{array}{l}\text { M: Locally applied to treat } \\
\text { warts }\end{array}$ & & 7 \\
\hline UNISGFRI028 & $(\mathrm{N})$ & & & & $\begin{array}{l}\text { M: Locally applied to treat } \\
\text { earache }\end{array}$ & 1 & \\
\hline Chenopodium bonus- & Spinacio selvatico, & 3 & 1 & & F: Litùn & 1 & \\
\hline $\begin{array}{l}\text { henricus L. } \\
\text { (Amaranthaceae) }\end{array}$ & $\begin{array}{l}\text { Spinazi del buon } \\
\text { enrico }(\mathrm{F})\end{array}$ & & & Leaves & F: Omelets & 3 & 1 \\
\hline Cichorium intybus $\mathrm{L}$. & & & & Aerial & F: Boiled & 2 & \\
\hline (Asteraceae) & & 0 & 1 & parts & F: Štakanje & & 1 \\
\hline$C l$ & Vitalba, Liane $(\mathrm{F})$, & 5 & 6 & & F: Omelets & 4 & 4 \\
\hline (Ranuncolaceae) & Gridiula (F), Lasà & & & Shoots & F: Litùn & 1 & \\
\hline UNISGFRI021 & $(\mathrm{N})$, Lazina $(\mathrm{N})$ & & & & F: Raw in salads & & 1 \\
\hline & Legabosco $(\mathrm{N})$ & & & & F: Soups & & 1 \\
\hline & & 7 & 11 & & F: Infusion in grappa & 7 & 4 \\
\hline Cornus mas L. & Quargno(F), Drìa & & & Fruits & F: Raw as a snack & & 4 \\
\hline (Cornaceae) & $(\mathrm{N})$ & & & & F: Vinegar* & & 1 \\
\hline & & & & & F: Jam & 2 & 2 \\
\hline Corylus avellana $\mathrm{L}$. & Nocciola, Liešink & 2 & 9 & Fruits & F: Desserts (Gubane, & 1 & 1 \\
\hline & & & & & F: Raw as a snack & 1 & 8 \\
\hline
\end{tabular}


This is the postprint version of the article:

Mattalia, G., Soukand, R., Corvo, P., \& Pieroni, A. (2020 Dissymmetry at the Border: Wild Food and Medicinal Ethnobotany of Slovenes and Friulians in Northeast Italy Economic Botany, 10.1007/s12231-020-09488-y.

\begin{tabular}{|c|c|c|c|c|c|c|c|}
\hline $\begin{array}{l}\text { Crataegus monogyna Ja } \\
\text { cq. (Rosaceae) }\end{array}$ & \multirow{2}{*}{$\begin{array}{l}\text { Biancospino, Tarin } \\
\text { (N) }\end{array}$} & 0 & 4 & \multirow[t]{2}{*}{ Flowers } & $\begin{array}{l}\text { M: Infusion to treat flu and } \\
\text { cough }\end{array}$ & & 3 \\
\hline UNISGFRI008 & & & & & M: Infusion ("it is healthy") & & 1 \\
\hline $\begin{array}{l}\text { Cynodon dactylon (L.) } \\
\text { Pers. (Poaceae) }\end{array}$ & Gramigna & 0 & 2 & Roots & $\begin{array}{l}\text { M: Infusion to treat urinary } \\
\text { tract inflammation }\end{array}$ & & 2 \\
\hline $\begin{array}{l}\text { Dioscorea communis } \\
\text { (L.) Caddick \& Wilkin. } \\
\text { (Dioscoreaceae) }\end{array}$ & Tamice & & & Shoots & F: Boiled & 2 & \\
\hline $\begin{array}{l}\text { Diplotaxis spp. } \\
\text { (Brassicaceae) }\end{array}$ & Rucola selvatica & 2 & 2 & $\begin{array}{l}\text { Aerial } \\
\text { parts }\end{array}$ & F: Raw in salads & 2 & 2 \\
\hline \multirow[t]{2}{*}{$\begin{array}{l}\text { Equisetum arvense L. } \\
\text { (Equisetaceae) }\end{array}$} & \multirow[t]{2}{*}{ Coda cavallina } & 3 & 0 & \multirow{2}{*}{$\begin{array}{l}\text { Aerial } \\
\text { parts }\end{array}$} & $\begin{array}{l}\text { M: Infusion to treat } \\
\text { bronchitis }\end{array}$ & 1 & \\
\hline & & & & & $\begin{array}{l}\text { M: Infusion to treat } \\
\text { rheumatism }\end{array}$ & 3 & \\
\hline \multirow{2}{*}{$\begin{array}{l}\text { Ficus carica } \mathrm{L} \text {. } \\
\text { (Moraceae) }\end{array}$} & \multirow[b]{2}{*}{ Fico } & 4 & 1 & Fruits & F: Jam & 2 & \\
\hline & & & & Latex & $\begin{array}{l}\text { M: Locally applied to treat } \\
\text { warts }\end{array}$ & 2 & 1 \\
\hline \multirow{8}{*}{ Foeniculum vulgare } & \multirow{8}{*}{$\begin{array}{l}\text { Fenule selvaje }(\mathrm{F}), \\
\text { Komarač }(\mathrm{N})\end{array}$} & 13 & 10 & \multirow{3}{*}{$\begin{array}{l}\text { Fresh } \\
\text { aerial } \\
\text { parts }\end{array}$} & $\mathrm{F}$ : Marve & & 3 \\
\hline & & & & & F: Soups & 3 & 1 \\
\hline & & & & & F: Omelets & 13 & 9 \\
\hline & & & & \multirow{2}{*}{ Seeds } & F: Infusion in grappa & 4 & 5 \\
\hline & & & & & F: Seasoning & 5 & \\
\hline & & & & \multirow{3}{*}{ Seeds } & M: Infusion as diuretic & & 3 \\
\hline & & & & & $\begin{array}{l}\text { M: Infusion to treat sore } \\
\text { throat }\end{array}$ & 5 & \\
\hline & & & & & $\begin{array}{l}\text { M: Decoction of } \\
\text { Parietaria officinalis, } \\
\text { Mentha spp., Melissa }\end{array}$ & 2 & \\
\hline
\end{tabular}


This is the postprint version of the article:

Mattalia, G., Soukand, R., Corvo, P., \& Pieroni, A. (2020 Dissymmetry at the Border: Wild Food and Medicinal Ethnobotany of Slovenes and Friulians in Northeast Italy Economic Botany, 10.1007/s12231-020-09488-y.

\begin{tabular}{|c|c|c|c|c|c|c|c|}
\hline & & & & & $\begin{array}{l}\text { officinalis, Foeniculum } \\
\text { vulgare, Origanum } \\
\text { majorana, Hedera spp. with } \\
\text { ash or vegetable charcoal to } \\
\text { detox }\end{array}$ & & \\
\hline & & & & & $\begin{array}{l}\text { M: Infusion to treat } \\
\text { abdominal pain }\end{array}$ & 1 & 3 \\
\hline & & & & Juice & $\begin{array}{l}\text { M: Locally applied to treat } \\
\text { warts }\end{array}$ & & 2 \\
\hline & & & & Dried & $\begin{array}{l}\text { M: Infusion for winter ("it's } \\
\text { healthy!") }\end{array}$ & & 1 \\
\hline & & & & flowers & $\begin{array}{l}\text { M: Infusion to treat } \\
\text { abdominal pain }\end{array}$ & & 1 \\
\hline & & 10 & 12 & & F: Raw as snack & 2 & 7 \\
\hline Fragaria vesca L. & Fragolina, Jaguca & & & Fruits & F: Liquor & 6 & \\
\hline (Rosaceae) & $(\mathrm{N})$ & & & & F: Syrup & & 1 \\
\hline UNISGFRI006 & & & & & F: Jam & 2 & 5 \\
\hline & & & & Flowers & F: Infusion in grappa & & 2 \\
\hline $\begin{array}{l}\text { Galium aparine L. } \\
\text { (Rubiaceae) } \\
\text { UNISGFRI035 }\end{array}$ & Aparina & 2 & 0 & $\begin{array}{l}\text { Aerial } \\
\text { parts }\end{array}$ & F: Litùn & 2 & \\
\hline $\begin{array}{l}\text { Galium odorata L. } \\
\text { (Rubiaceae) }\end{array}$ & Asperula & 0 & 1 & $\begin{array}{l}\text { Aerial } \\
\text { parts }\end{array}$ & F: Liquor & & 1 \\
\hline Gentiana lutea L. & & 5 & 3 & & F: Infusion in white wine & 4 & 3 \\
\hline (Gentianaceae) & & & & & F: Infusion in grappa & 5 & \\
\hline & Karšutnjak (N) & & & Roots & $\begin{array}{l}\text { M: Infusion in grappa to get } \\
\text { an ointment to treat joint } \\
\text { pain }\end{array}$ & & 1 \\
\hline
\end{tabular}


This is the postprint version of the article:

Mattalia, G., Soukand, R., Corvo, P., \& Pieroni, A. (2020 Dissymmetry at the Border: Wild Food and Medicinal Ethnobotany of Slovenes and Friulians in Northeast Italy Economic Botany, 10.1007/s12231-020-09488-y.

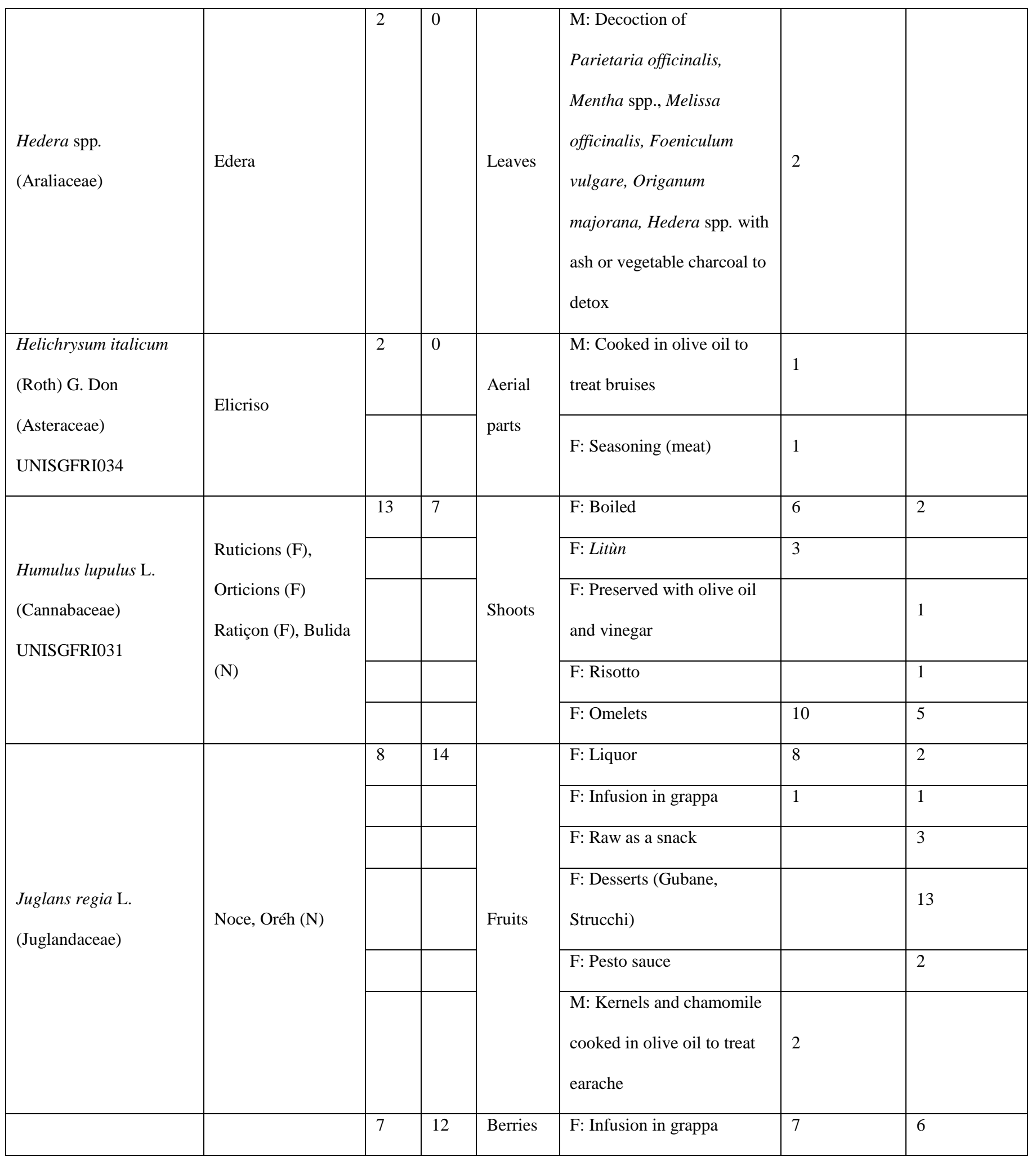


This is the postprint version of the article:

Mattalia, G., Soukand, R., Corvo, P., \& Pieroni, A. (2020 Dissymmetry at the Border: Wild Food and Medicinal Ethnobotany of Slovenes and Friulians in Northeast Italy Economic Botany, 10.1007/s12231-020-09488-y.

\begin{tabular}{|c|c|c|c|c|c|c|c|}
\hline \multirow{3}{*}{$\begin{array}{l}\text { Juniperus communis L. } \\
\text { (Cupressaceae) }\end{array}$} & \multirow{3}{*}{$\begin{array}{l}\text { Ginepro, Brienje } \\
\text { (N) }\end{array}$} & & & & F: Seasoning & 6 & 6 \\
\hline & & & & & $\begin{array}{l}\text { M: Infusion in grappa to get } \\
\text { an ointment to be applied } \\
\text { on umbilicus to treat } \\
\text { abdominal pain }\end{array}$ & & 7 \\
\hline & & & & & $\begin{array}{l}\text { M: Infusion in grappa to } \\
\text { treat rheumatism }\end{array}$ & & 1 \\
\hline $\begin{array}{l}\text { Lactuca alpina }(\mathrm{L} .) \\
\text { A.Gray (Asteraceae) }\end{array}$ & $\begin{array}{l}\text { Radicchio } \\
\text { selvatico, Radic di } \\
\text { mont (F) }\end{array}$ & 9 & 4 & $\begin{array}{l}\text { Aerial } \\
\text { parts }\end{array}$ & $\begin{array}{l}\text { F: Preserved with olive oil } \\
\text { and vinegar }\end{array}$ & 9 & 4 \\
\hline $\begin{array}{l}\text { Lamium spp. } \\
\text { (Lamiaceae) }\end{array}$ & $\begin{array}{l}\text { Falsa Ortica, Ortica } \\
\text { che non scotta }\end{array}$ & 1 & 0 & Leaves & F: Omelets & 1 & \\
\hline $\begin{array}{l}\text { Larix decidua Mill. } \\
\text { (Pinaceae) }\end{array}$ & Larice & 0 & 1 & Shoots & F: Infusion in grappa & & 1 \\
\hline $\begin{array}{l}\text { Laurus nobilis L. } \\
\text { (Lauraceae) }\end{array}$ & Lauro, Alloro & 3 & 1 & Leaves & F: Seasoning & 3 & 1 \\
\hline \multirow{3}{*}{$\begin{array}{l}\text { Levisticum officinale } \mathrm{W} \text {. } \\
\text { D.J.Koch (Apiaceae) }\end{array}$} & \multirow{3}{*}{$\begin{array}{l}\text { Levistico, Selin } \\
(\mathrm{F}), \text { Luštrih (N) }\end{array}$} & 9 & 14 & \multirow{3}{*}{$\begin{array}{l}\text { Aerial } \\
\text { parts }\end{array}$} & F: Omelets & 6 & 13 \\
\hline & & & & & F: Infusion in grappa & 7 & 1 \\
\hline & & & & & F: Soups & 1 & 1 \\
\hline \multirow{5}{*}{ Malus spp. (Rosaceae) } & \multirow{5}{*}{ Mela, Jabka (N) } & 4 & 6 & \multirow{4}{*}{ Fruits } & F: Raw as a snack & 3 & 2 \\
\hline & & & & & F: Juice & & 1 \\
\hline & & & & & F: Cider & & 2 \\
\hline & & & & & F: Dried & & 3 \\
\hline & & & & Seeds & F: Infusion in grappa & 1 & 3 \\
\hline \multirow{4}{*}{$\begin{array}{l}\text { Malva sylvestris L. } \\
\text { (Malvaceae) }\end{array}$} & \multirow{4}{*}{ Malva, Slis (N) } & 13 & 12 & \multirow{4}{*}{$\begin{array}{l}\text { Fresh or } \\
\text { dried } \\
\text { aerial } \\
\text { parts }\end{array}$} & F: Infusion in grappa & 3 & \\
\hline & & & & & F: Litùn & 1 & \\
\hline & & & & & F: Omelets & 1 & 3 \\
\hline & & & & & F: Štakanje & & 1 \\
\hline
\end{tabular}


This is the postprint version of the article:

Mattalia, G., Soukand, R., Corvo, P., \& Pieroni, A. (2020 Dissymmetry at the Border: Wild Food and Medicinal Ethnobotany of Slovenes and Friulians in Northeast Italy Economic Botany, 10.1007/s12231-020-09488-y.

\begin{tabular}{|c|c|c|c|c|c|c|c|}
\hline & & & & (esp. & F: Soups & & 1 \\
\hline & & & & Flowers & F: Raw in salads & & 1 \\
\hline & & & & ) & $\begin{array}{l}\text { M: Infusion to treat } \\
\text { hemorrhoids }\end{array}$ & 3 & \\
\hline & & & & & $\begin{array}{l}\text { M: Infusion for lavages } \\
\text { (also vet) }\end{array}$ & 6 & 3 \\
\hline & & & & & $\begin{array}{l}\text { M: Infusion to treat } \\
\text { inflammation }\end{array}$ & 4 & 4 \\
\hline & & & & & M: Fomentation to treat flu & 2 & \\
\hline & & & & & M: Infusion as refreshing & 6 & \\
\hline & & & & & $\begin{array}{l}\text { M: Infusion locally applied } \\
\text { to treat eyes }\end{array}$ & 2 & 1 \\
\hline & & & & & M: Infusion to treat kidneys & 2 & \\
\hline & & & & & M: Infusion as tranquilizer & 1 & 4 \\
\hline & & & & & $\begin{array}{l}\text { M: Infusion to treat } \\
\text { toothache }\end{array}$ & 4 & 2 \\
\hline & & & & & $\begin{array}{l}\text { M: Infusion to treat } \\
\text { (phlegm) cough and flu }\end{array}$ & 1 & \\
\hline & & & & & $\begin{array}{l}\text { M: Decoction to treat } \\
\text { stomach pain }\end{array}$ & & 2 \\
\hline & & & & & M: Poultice to treat swelling & & 5 \\
\hline & & & & & $\begin{array}{l}\text { M: Infusion as laxative and } \\
\text { diuretic }\end{array}$ & 2 & 4 \\
\hline & & 13 & 9 & & F: Soups & & 1 \\
\hline & & & & & F: Infusion in grappa & 2 & \\
\hline L. (Asteraceae) & & & & & $\begin{array}{l}\text { M: Dried and then cooked } \\
\text { in olive oil as soothing* }\end{array}$ & 2 & \\
\hline
\end{tabular}


This is the postprint version of the article:

Mattalia, G., Soukand, R., Corvo, P., \& Pieroni, A. (2020 Dissymmetry at the Border: Wild Food and Medicinal Ethnobotany of Slovenes and Friulians in Northeast Italy Economic Botany, 10.1007/s12231-020-09488-y.

\begin{tabular}{|c|c|c|c|c|c|c|c|}
\hline & & & & & M: Infusion as tranquilizer & 5 & 7 \\
\hline & & & & & $\begin{array}{l}\text { M: Dried and then cooked } \\
\text { in olive oil to treat sprains* }\end{array}$ & 2 & \\
\hline & & & & & $\begin{array}{l}\text { M: Dried and then cooked } \\
\text { in olive oil to treat earache* }\end{array}$ & 4 & \\
\hline & & & & & $\begin{array}{l}\text { M: Infusion with salt as } \\
\text { digestive* }\end{array}$ & 1 & \\
\hline & & & & & $\begin{array}{l}\text { M: Infusion to treat } \\
\text { headache }\end{array}$ & & 3 \\
\hline & & & & & $\begin{array}{l}\text { M: Infusion locally applied } \\
\text { to treat eyes }\end{array}$ & & 2 \\
\hline $\begin{array}{l}\text { Medicago sativa L. } \\
\text { (Leguminosae) } \\
\text { UNISGFRI007 }\end{array}$ & Arba menica $(\mathrm{F})$ & 3 & 0 & Shoots & F: Litùn & 3 & \\
\hline & & 9 & 5 & & F: Infusion in grappa & 4 & 2 \\
\hline & & & & & F: Omelets & 6 & 4 \\
\hline & & & & & M: Infusion as tranquilizer & 1 & \\
\hline $\begin{array}{l}\text { Melissa officinalis L. } \\
\text { (Lamiaceae) }\end{array}$ & $\begin{array}{l}\text { Melissa, } \\
\text { Sarcnozeie (N) }\end{array}$ & & & $\begin{array}{l}\text { Aerial } \\
\text { parts }\end{array}$ & $\begin{array}{l}\text { M: Decoction of } \\
\text { Parietaria officinalis, } \\
\text { Mentha spp., Melissa } \\
\text { officinalis, Foeniculum } \\
\text { vulgare, Origanum } \\
\text { majorana, Hedera spp. with } \\
\text { ash or vegetable charcoal to } \\
\text { detox }\end{array}$ & 2 & \\
\hline & & & & & $\begin{array}{l}\text { M: Infusion to treat } \\
\text { (phlegm), cough and flu }\end{array}$ & 1 & \\
\hline & & 15 & 10 & Leaves & M: Infusion to treat cough & & 3 \\
\hline
\end{tabular}


This is the postprint version of the article:

Mattalia, G., Soukand, R., Corvo, P., \& Pieroni, A. (2020 Dissymmetry at the Border: Wild Food and Medicinal Ethnobotany of Slovenes and Friulians in Northeast Italy Economic Botany, 10.1007/s12231-020-09488-y.

\begin{tabular}{|c|c|c|c|c|c|c|c|}
\hline \multirow{7}{*}{$\begin{array}{l}\text { Mentha spp. } \\
\text { (Lamiaceae) } \\
\text { (arvensis L.) } \\
\text { UNISGFRI023 } \\
\text { (piperita L.) } \\
\text { UNISGFRI010 }\end{array}$} & \multirow[t]{7}{*}{$\begin{array}{l}\text { Menta, Mentuccia, } \\
\text { Meta }(\mathrm{N})\end{array}$} & & & & $\begin{array}{l}\text { M: Decoction of } \\
\text { Parietaria officinalis, } \\
\text { Mentha spp., Melissa } \\
\text { officinalis, Foeniculum } \\
\text { vulgare, Origanum } \\
\text { majorana, Hedera spp. with } \\
\text { ash or vegetable charcoal to } \\
\text { detox } \\
\text { M: Infusion as a digestive }\end{array}$ & 2 & 2 \\
\hline & & & & & F: Mojito & 2 & 2 \\
\hline & & & & & F: Omelets & 12 & 4 \\
\hline & & & & & F: Infusion in grappa & 5 & \\
\hline & & & & & F: Marve & & 2 \\
\hline & & & & & F: Seasoning & 3 & 5 \\
\hline & & & & & F: Recreational tea & 2 & \\
\hline $\begin{array}{l}\text { Mespilus germanica L. } \\
\text { (Rosaceae) }\end{array}$ & Manzeolo (F) & 1 & 0 & Fruits & F: Raw as a snack & 1 & \\
\hline \multirow[b]{4}{*}{$\begin{array}{l}\text { Origanum majorana L. } \\
\text { (Lamiaceae) }\end{array}$} & \multirow[b]{4}{*}{ Maggiorana } & 6 & 3 & & F: Omelets & 4 & \\
\hline & & & & & F: Seasoning (dried) & 1 & 3 \\
\hline & & & & & F: Infusion in grappa & 1 & \\
\hline & & & & $\begin{array}{l}\text { Aerial } \\
\text { parts }\end{array}$ & $\begin{array}{l}\text { M: Decoction of } \\
\text { Parietaria officinalis, } \\
\text { Mentha spp., Melissa } \\
\text { officinalis, Foeniculum } \\
\text { vulgare, Origanum } \\
\text { majorana with ash or } \\
\text { vegetable charcoal to detox }\end{array}$ & 2 & \\
\hline
\end{tabular}


This is the postprint version of the article:

Mattalia, G., Soukand, R., Corvo, P., \& Pieroni, A. (2020 Dissymmetry at the Border: Wild Food and Medicinal Ethnobotany of Slovenes and Friulians in Northeast Italy Economic Botany, 10.1007/s12231-020-09488-y.

\begin{tabular}{|c|c|c|c|c|c|c|c|}
\hline & & & & & $\begin{array}{l}\text { M: Infusion to treat } \\
\text { abdominal pain }\end{array}$ & & 1 \\
\hline \multirow{2}{*}{$\begin{array}{l}\text { Origanum vulgare L. } \\
\text { (Lamiaceae) }\end{array}$} & \multirow[b]{2}{*}{ Origano } & 3 & 3 & \multirow{2}{*}{$\begin{array}{l}\text { Aerial } \\
\text { parts }\end{array}$} & F: Seasoning & & 2 \\
\hline & & & & & F: Omelets & 3 & 1 \\
\hline \multirow{4}{*}{$\begin{array}{l}\text { Papaver rhoeas L. } \\
\text { (Papaveraceae) }\end{array}$} & \multirow{4}{*}{ Confenon $(\mathrm{F})$} & 5 & 0 & \multirow{4}{*}{$\begin{array}{l}\text { Aerial } \\
\text { parts }\end{array}$} & F: Crespelle & 1 & \\
\hline & & & & & F: Omelets & 1 & \\
\hline & & & & & F: Litùn & 3 & \\
\hline & & & & & $\begin{array}{l}\text { M: Decoction "to fix } \\
\text { bones"* }\end{array}$ & 1 & \\
\hline \multirow{3}{*}{$\begin{array}{l}\text { Parietaria officinalis L. } \\
\text { (Urticaceae) } \\
\text { UNISGFRI026 }\end{array}$} & \multirow{3}{*}{ Parietaria } & 4 & 2 & \multirow{3}{*}{$\begin{array}{l}\text { Aerial } \\
\text { parts }\end{array}$} & F: Omelets & 2 & 2 \\
\hline & & & & & $\begin{array}{l}\text { M: Decoction of } \\
\text { Parietaria officinalis, } \\
\text { Mentha spp., Melissa } \\
\text { officinalis, Foeniculum } \\
\text { vulgare, Origanum } \\
\text { majorana, Hedera spp. with } \\
\text { ash or vegetable charcoal to } \\
\text { detox }\end{array}$ & 2 & \\
\hline & & & & & M: Infusion as laxative & 2 & \\
\hline \multirow{2}{*}{$\begin{array}{l}\text { Petroselinum crispum ( } \\
\text { Mill.) Fuss (Apiaceae) }\end{array}$} & \multirow{2}{*}{$\begin{array}{l}\text { Prezzemolo, Savors } \\
\text { (F) }\end{array}$} & 6 & 3 & \multirow{2}{*}{$\begin{array}{l}\text { Aerial } \\
\text { parts }\end{array}$} & F: Infusion in grappa & & 2 \\
\hline & & & & & F: Omelets & 6 & 3 \\
\hline \multirow{4}{*}{$\begin{array}{l}\text { Pinus mugo Turra } \\
\text { (Pinaceae) }\end{array}$} & \multirow{4}{*}{ Pino mugo } & 4 & 7 & \multirow{4}{*}{ Shoots } & F: Infusion in grappa & & 4 \\
\hline & & & & & M: Infusion as laxative & 1 & \\
\hline & & & & & $\begin{array}{l}\text { M: Distillate to treat } \\
\text { bronchitis }\end{array}$ & 1 & \\
\hline & & & & & M: Fomentation to treat flu & 1 & \\
\hline
\end{tabular}


This is the postprint version of the article:

Mattalia, G., Soukand, R., Corvo, P., \& Pieroni, A. (2020 Dissymmetry at the Border: Wild Food and Medicinal Ethnobotany of Slovenes and Friulians in Northeast Italy Economic Botany, 10.1007/s12231-020-09488-y.

\begin{tabular}{|c|c|c|c|c|c|c|c|}
\hline & & & & & $\begin{array}{l}\text { M: Syrup to treat cough and } \\
\text { phlegm }\end{array}$ & 2 & 3 \\
\hline Pinus spp. (Pinaceae) & Pino & 0 & 3 & Shoots & F: Infusion in grappa & & 3 \\
\hline $\begin{array}{l}\text { Pinus strobus L. } \\
\text { (Pinaceae) }\end{array}$ & Pino strobo & 0 & 1 & Shoots & F: Infusion in grappa & & 1 \\
\hline \multirow{7}{*}{$\begin{array}{l}\text { Plantago lanceolata } \mathrm{L} \text {. } \\
\text { (Plantaginaceae) }\end{array}$} & \multirow{7}{*}{$\begin{array}{l}\text { Plantain }(\mathrm{F}) \text {, } \\
\operatorname{Tarpotac}(\mathrm{N})\end{array}$} & 3 & 7 & \multirow{7}{*}{ Leaves } & F: Omelets & 1 & 3 \\
\hline & & & & & F: Litùn & 3 & \\
\hline & & & & & F: Štakanje & & 1 \\
\hline & & & & & F: Infusion in grappa & & 2 \\
\hline & & & & & $\begin{array}{l}\text { M: Infusion to treat } \\
\text { abdominal pain }\end{array}$ & & 2 \\
\hline & & & & & $\begin{array}{l}\text { M: Ointment with pork fat } \\
\text { to treat skin }\end{array}$ & & 2 \\
\hline & & & & & $\begin{array}{l}\text { M: Locally applied as } \\
\text { cicatrizer }\end{array}$ & 1 & 5 \\
\hline $\begin{array}{l}\text { Portulaca oleracea L. } \\
\text { (Portulacaceae) }\end{array}$ & No name & 3 & 1 & $\begin{array}{l}\text { Aerial } \\
\text { parts }\end{array}$ & F: Raw in salads & 3 & 1 \\
\hline \multirow{6}{*}{$\begin{array}{l}\text { Primula spp. } \\
\text { (Primulaceae) }\end{array}$} & \multirow{6}{*}{$\begin{array}{l}\text { Primula Pastalà }(\mathrm{F}), \\
\text { Piskàlca }(\mathrm{N})\end{array}$} & 3 & 3 & \multirow{2}{*}{ Leaves } & F: Omelets & & 2 \\
\hline & & & & & F: Infusion in grappa & & 2 \\
\hline & & & & \multirow{4}{*}{ Flowers } & F: Litùn & 3 & \\
\hline & & & & & F: Raw in salads & & 1 \\
\hline & & & & & $\mathrm{F}$ : Infusion in grappa & 1 & 1 \\
\hline & & & & & M: Infusion as detox & & 1 \\
\hline \multirow[t]{2}{*}{$\begin{array}{l}\text { Primula veris L. } \\
\text { (Primulaceae) }\end{array}$} & Cuculucia (F) & 2 & 0 & Flowers & F: Litùn & 2 & \\
\hline & & 8 & 4 & Fruits & F: Preserved with alcohol & 1 & 1 \\
\hline
\end{tabular}


This is the postprint version of the article:

Mattalia, G., Soukand, R., Corvo, P., \& Pieroni, A. (2020 Dissymmetry at the Border: Wild Food and Medicinal Ethnobotany of Slovenes and Friulians in Northeast Italy Economic Botany, 10.1007/s12231-020-09488-y.

\begin{tabular}{|c|c|c|c|c|c|c|c|}
\hline \multirow{4}{*}{$\begin{array}{l}\text { Prunus cerasus L. } \\
\text { (Rosaceae) }\end{array}$} & \multirow{4}{*}{$\begin{array}{l}\text { Ciliegio, Carìessnj } \\
\text { (N) }\end{array}$} & & & & $\begin{array}{l}\text { F: Preserved with alcohol } \\
\text { (Pentolaccia russa) }\end{array}$ & 1 & 3 \\
\hline & & & & & F: Liquor & 5 & \\
\hline & & & & & F: Jam & 1 & 1 \\
\hline & & & & & F: Raw as a snack & 1 & \\
\hline \multirow{6}{*}{$\begin{array}{l}\text { Prunus domestica L. } \\
\text { (Rosaceae) }\end{array}$} & \multirow{6}{*}{$\begin{array}{l}\text { Prugno, Susino, } \\
\text { Čiešpa (N) }\end{array}$} & 5 & 10 & \multirow{6}{*}{ Fruits } & F: Jam & 1 & 1 \\
\hline & & & & & F: Dried & & 2 \\
\hline & & & & & $\begin{array}{l}\text { F: Preserved with alcohol } \\
\text { (Pentolaccia russa) }\end{array}$ & 1 & 6 \\
\hline & & & & & F: Raw as a snack & & 1 \\
\hline & & & & & F: Liquor & 2 & 1 \\
\hline & & & & & $\begin{array}{l}\text { M: Dried or boiled as } \\
\text { laxative }\end{array}$ & 2 & 1 \\
\hline $\begin{array}{l}\text { Prunus spinosa } \mathrm{L} . \\
\text { (Rosaceae) }\end{array}$ & Brugnolo $(\mathrm{F})$ & 1 & 0 & Fruits & F: Infusion in grappa & 1 & \\
\hline \multirow{3}{*}{$\begin{array}{l}\text { Pulmonaria officinalis } \mathrm{L} \\
\text {. (Boraginaceae) }\end{array}$} & \multirow{3}{*}{$\begin{array}{l}\text { Polmonaria } \\
\text { Plucniak (N) }\end{array}$} & 2 & 4 & \multirow{3}{*}{$\begin{array}{l}\text { Aerial } \\
\text { parts }\end{array}$} & F: Omelets & & 2 \\
\hline & & & & & F: Infusion in grappa & & 2 \\
\hline & & & & & F: Litùn & 2 & \\
\hline \multirow{4}{*}{ Pyrus spp. (Rosaceae) } & \multirow{4}{*}{ Pere, Hru`ska (N) } & 2 & 8 & \multirow{4}{*}{ Fruits } & F: Raw as a snack & 1 & 2 \\
\hline & & & & & F: Dried and then in soups & & 6 \\
\hline & & & & & F: Cider & & 2 \\
\hline & & & & & $\begin{array}{l}\text { F: Preserved with alcohol } \\
\text { (Pentolaccia russa) }\end{array}$ & 1 & 3 \\
\hline \multirow{2}{*}{$\begin{array}{l}\text { Rheum officinale Bill.. } \\
\text { (Polygonaceae) }\end{array}$} & \multirow[b]{2}{*}{ Rabarbaro } & 3 & 1 & Stems & F: Jam & 3 & 1 \\
\hline & & & & $\begin{array}{l}\text { Dried } \\
\text { roots }\end{array}$ & F: Infusion in grappa & 1 & \\
\hline \multirow{2}{*}{$\begin{array}{l}\text { Robinia pseudoacacia } \mathrm{L} \text {. } \\
\text { (Leguminosae) }\end{array}$} & \multirow{2}{*}{$\begin{array}{l}\text { Acacia, Acasia }(\mathrm{F}) \text {, } \\
\text { Akàcja }(\mathrm{N})\end{array}$} & 15 & 8 & \multirow{2}{*}{ Flowers } & F: Battered fried & 13 & 5 \\
\hline & & & & & F: Jam & 3 & 1 \\
\hline
\end{tabular}


This is the postprint version of the article:

Mattalia, G., Soukand, R., Corvo, P., \& Pieroni, A. (2020 Dissymmetry at the Border: Wild Food and Medicinal Ethnobotany of Slovenes and Friulians in Northeast Italy Economic Botany, 10.1007/s12231-020-09488-y.

\begin{tabular}{|c|c|c|c|c|c|c|c|}
\hline \multirow[t]{4}{*}{ UNISGFRI015 } & & & & & $\mathrm{F}$ : Infusion in grappa & 3 & 1 \\
\hline & & & & & F: Dessert & & 1 \\
\hline & & & & & F: Syrup & & 2 \\
\hline & & & & & M: Infusion to treat flu & & 3 \\
\hline \multirow{4}{*}{$\begin{array}{l}\text { Rosa canina L. } \\
\text { (Rosaceae) } \\
\text { UNISGFRI030 }\end{array}$} & \multirow{4}{*}{$\begin{array}{l}\text { Rosa Canina, } \\
\text { Pizzacui (F), Tàrnje } \\
\text { (N) }\end{array}$} & 7 & 10 & \multirow{4}{*}{$\begin{array}{l}\text { Fruits, } \\
\text { Flowers }\end{array}$} & F: Infusion in grappa & 3 & \\
\hline & & & & & F: Jelly & 1 & \\
\hline & & & & & F: Jam & 1 & 7 \\
\hline & & & & & M: Infusion ("it is healthy") & 3 & 6 \\
\hline \multirow{4}{*}{$\begin{array}{l}\text { Rosmarinus officinalis } \\
\text { L. (Lamiaceae) }\end{array}$} & \multirow{4}{*}{$\begin{array}{l}\text { Rosmarino, } \\
\text { Rožmarin }(\mathrm{N})\end{array}$} & 3 & 2 & \multirow{4}{*}{$\begin{array}{l}\text { Aerial } \\
\text { parts }\end{array}$} & F: Battered fried & 1 & \\
\hline & & & & & F: Seasoning (dried) & & 2 \\
\hline & & & & & F: Infusion in grappa & 1 & 1 \\
\hline & & & & & F: Omelets & 2 & \\
\hline \multirow{4}{*}{$\begin{array}{l}\text { Rubus idaeus L. } \\
\text { (Rosaceae) } \\
\text { UNISGFRI011 }\end{array}$} & \multirow{4}{*}{$\begin{array}{l}\text { Lampone, Màlinči } \\
\text { (N) }\end{array}$} & 6 & 12 & \multirow{4}{*}{ Fruits } & F: Raw as a snack & 1 & 7 \\
\hline & & & & & F: Jam & 1 & 5 \\
\hline & & & & & F: Syrup & & 1 \\
\hline & & & & & F: Liquor & 6 & \\
\hline \multirow{7}{*}{ Rubus ulmifolius Schott } & \multirow{7}{*}{$\begin{array}{l}\text { Baraç, Punta di } \\
\text { rovo, Arbidenze } \\
\text { (N) }\end{array}$} & 9 & 13 & \multirow{3}{*}{ Fruits } & F: Jam & 3 & 2 \\
\hline & & & & & F: Raw as a snack & & 10 \\
\hline & & & & & F: Liquor & 3 & \\
\hline & & & & Flowers & M: Infusion as tranquilizer & & 1 \\
\hline & & & & \multirow{3}{*}{ Shoots } & F: Litùn & 5 & \\
\hline & & & & & F: Omelets & & 1 \\
\hline & & & & & F: Soups & & 1 \\
\hline \multirow{2}{*}{$\begin{array}{l}\text { Rumex acetosa L. } \\
\text { (Polygonaceae) }\end{array}$} & \multirow{2}{*}{$\begin{array}{l}\text { Pan e vin e uelle } \\
(\mathrm{F}) \text {, Acetosa di } \\
\text { Bella Ville }\end{array}$} & 4 & 0 & \multirow[b]{2}{*}{ Leaves } & F: Litùn & 2 & \\
\hline & & & & & F: Raw in salads & 2 & \\
\hline \multirow{2}{*}{$\begin{array}{l}\text { Rumex acetosella L. } \\
\text { (Polygonaceae) }\end{array}$} & \multirow{2}{*}{ Kiselza (N) } & 0 & 2 & \multirow{2}{*}{$\begin{array}{l}\text { Aerial } \\
\text { parts }\end{array}$} & F: Omelets & & 1 \\
\hline & & & & & F: Raw in salads & & 1 \\
\hline
\end{tabular}


This is the postprint version of the article:

Mattalia, G., Soukand, R., Corvo, P., \& Pieroni, A. (2020 Dissymmetry at the Border: Wild Food and Medicinal Ethnobotany of Slovenes and Friulians in Northeast Italy Economic Botany, 10.1007/s12231-020-09488-y.

\begin{tabular}{|c|c|c|c|c|c|c|c|}
\hline & & & & & F: Soups & & 1 \\
\hline \multirow{3}{*}{$\begin{array}{l}\text { Rumex obtusifolius L. } \\
\text { (Polygonaceae) } \\
\text { UNISGFRI003 }\end{array}$} & \multirow{3}{*}{ Linga di vachia $(\mathrm{F})$} & 5 & 0 & \multirow{3}{*}{ Leaves } & F: Pesto sauce & 1 & \\
\hline & & & & & F: Litùn & 1 & \\
\hline & & & & & $\begin{array}{l}\text { M: Locally applied to treat } \\
\text { insect stings or warts }\end{array}$ & 3 & \\
\hline \multirow{4}{*}{$\begin{array}{l}\text { Ruscus aculeatus L. } \\
\text { (Asparagaceae) } \\
\text { UNISGFRI005 }\end{array}$} & \multirow{4}{*}{$\begin{array}{l}\text { Rusculin }(F), \\
\text { Rasculin }(F), \\
\text { Pungitopo }\end{array}$} & 11 & 1 & \multirow{4}{*}{ Stems } & F: Boiled with eggs & 6 & 1 \\
\hline & & & & & F: Preserved with vinegar & 1 & \\
\hline & & & & & F: Boiled and then in salads & 3 & \\
\hline & & & & & F: Omelets & 1 & \\
\hline \multirow{5}{*}{$\begin{array}{l}\text { Ruta graveolens L. } \\
\text { (Rutaceae) } \\
\text { UNISGFRI016 }\end{array}$} & \multirow{5}{*}{ Ruta, Grutca (N) } & 6 & 14 & \multirow{4}{*}{ Leaves } & F: Omelets & & 2 \\
\hline & & & & & $\begin{array}{l}\text { M: Locally applied to treat } \\
\text { insect stings or warts }\end{array}$ & 6 & 7 \\
\hline & & & & & $\begin{array}{l}\text { M: Coffee with Ruta and } \\
\text { Artemisia absinthium to } \\
\text { treat abdominal pain }\end{array}$ & & 1 \\
\hline & & & & & $\begin{array}{l}\text { M: Chewed to treat } \\
\text { abdominal pain }\end{array}$ & & 3 \\
\hline & & & & Flowers & F: Soups & & 1 \\
\hline \multirow{7}{*}{ Salvia spp. (Lamiaceae) } & \multirow{7}{*}{ Salvia, Salvija (N) } & 8 & 10 & \multirow{7}{*}{ Leaves } & F: Battered fried & 3 & \\
\hline & & & & & F: Omelets & 1 & 2 \\
\hline & & & & & F: Seasoning (dried) & 1 & 2 \\
\hline & & & & & F: Infusion in grappa & & 1 \\
\hline & & & & & $\begin{array}{l}\text { M: Distillate to treat hot } \\
\text { flashes* }\end{array}$ & 1 & \\
\hline & & & & & $\begin{array}{l}\text { M: Infusion to treat } \\
\text { toothache* }\end{array}$ & 2 & \\
\hline & & & & & $\begin{array}{l}\text { M: Infusion with lemon as } \\
\text { digestive }\end{array}$ & 1 & \\
\hline
\end{tabular}


This is the postprint version of the article:

Mattalia, G., Soukand, R., Corvo, P., \& Pieroni, A. (2020 Dissymmetry at the Border: Wild Food and Medicinal Ethnobotany of Slovenes and Friulians in Northeast Italy Economic Botany, 10.1007/s12231-020-09488-y.

\begin{tabular}{|c|c|c|c|c|c|c|c|}
\hline & & & & & $\begin{array}{l}\text { M: Chewed to treat } \\
\text { toothache* }\end{array}$ & 3 & 4 \\
\hline & & & & & $\begin{array}{l}\text { M: Boiled in milk to treat } \\
\text { cough* }\end{array}$ & 2 & 3 \\
\hline & & & & & $\begin{array}{l}\text { M: Boiled in milk and } \\
\text { honey to treat bronchitis* }\end{array}$ & 2 & \\
\hline & & & & & $\begin{array}{l}\text { M: Infusion to treat sore } \\
\text { throat }\end{array}$ & & 5 \\
\hline & & & & & $\begin{array}{l}\text { M: Infusion in grappa to } \\
\text { treat cough* }\end{array}$ & 3 & \\
\hline \multirow{9}{*}{ Sambucus nigra $\mathrm{L}$. } & \multirow{9}{*}{$\begin{array}{l}\text { Sambuco, } \\
\text { Bazovina (N) }\end{array}$} & 15 & 15 & \multirow{5}{*}{ Flowers } & F: Battered fried & 9 & 6 \\
\hline & & & & & F: Infusion in grappa & 4 & 2 \\
\hline & & & & & $\begin{array}{l}\text { M: Syrup in warm water to } \\
\text { treat cough and phlegm }\end{array}$ & 8 & 7 \\
\hline & & & & & M: Poultice to treat swelling & & 1 \\
\hline & & & & & $\begin{array}{l}\text { M: Syrup in cold water as } \\
\text { refreshing and diuretic }\end{array}$ & 6 & 9 \\
\hline & & & & \multirow{2}{*}{$\begin{array}{l}\text { Dried or } \\
\text { fresh } \\
\text { flowers }\end{array}$} & $\begin{array}{l}\text { F: Seasoning for pasta (e.g. } \\
\text { gnocchi) }\end{array}$ & & 1 \\
\hline & & & & & M: Infusion as tranquilizer & & 8 \\
\hline & & & & \multirow{2}{*}{ Fruits } & F: Infusion in grappa & & 2 \\
\hline & & & & & F: Jam & 1 & 2 \\
\hline $\begin{array}{l}\text { Sanguisorba minor subs } \\
\text { p. balearica (Bourg. ex } \\
\text { Nyman) Muñoz Garm. } \\
\text { \& C.Navarro (Rosaceae) }\end{array}$ & Pimpinella & 2 & 0 & Leaves & F: Raw in salads & 2 & \\
\hline \multirow{2}{*}{$\begin{array}{l}\text { Satureja montana L. } \\
\text { (Lamiaceae) }\end{array}$} & \multirow{2}{*}{ Santoreggia } & 2 & 2 & \multirow{2}{*}{ Leaves } & F: Seasoning (dried) & & 1 \\
\hline & & & & & F: Omelets & 2 & 1 \\
\hline
\end{tabular}


This is the postprint version of the article:

Mattalia, G., Soukand, R., Corvo, P., \& Pieroni, A. (2020 Dissymmetry at the Border: Wild Food and Medicinal Ethnobotany of Slovenes and Friulians in Northeast Italy Economic Botany, 10.1007/s12231-020-09488-y.

\begin{tabular}{|c|c|c|c|c|c|c|c|}
\hline $\begin{array}{l}\text { Sedum telephium } \mathrm{L} . \\
\text { (Crassulaceae) }\end{array}$ & $\begin{array}{l}\text { Erba di San } \\
\text { Giovanni }\end{array}$ & 0 & 1 & Leaves & F: Omelets & & 1 \\
\hline $\begin{array}{l}\text { Sempervivum tectorum } \\
\text { L. (Crassulaceae) } \\
\text { UNISGFRI027 }\end{array}$ & Natresk (N) & 1 & 6 & Leaves & $\begin{array}{l}\text { M: Juice applied to treat } \\
\text { earache }\end{array}$ & 1 & 6 \\
\hline \multirow{3}{*}{$\begin{array}{l}\text { Silene vulgaris } \\
\text { (Moench) Garcke } \\
\text { (Caryophyllaceae) }\end{array}$} & \multirow{5}{*}{$\begin{array}{l}\text { Sclupit }(\mathrm{F}), \\
\text { Pokolza }(\mathrm{N})\end{array}$} & 15 & 12 & \multirow{5}{*}{$\begin{array}{l}\text { Aerial } \\
\text { parts }\end{array}$} & F: Omelets & 11 & 10 \\
\hline & & & & & F: Soups & 1 & 6 \\
\hline & & & & & F: Pesto sauce & 1 & 1 \\
\hline \multirow[t]{2}{*}{ UNISGFRI018 } & & & & & F: Litùn & 6 & \\
\hline & & & & & F: Risotto & 4 & 7 \\
\hline $\begin{array}{l}\text { Solanum dulcamara L. } \\
\text { (Solanaceae) }\end{array}$ & Ducamara & 3 & 0 & Leaves & F: Omelets & 3 & \\
\hline \multirow{3}{*}{$\begin{array}{l}\text { Sonchus oleraceaus } \\
\text { L.(Asteraceae) }\end{array}$} & \multirow{3}{*}{ Latisul (F) } & 2 & 0 & \multirow{3}{*}{$\begin{array}{l}\text { Aerial } \\
\text { parts }\end{array}$} & F: Omelets & 1 & \\
\hline & & & & & $\begin{array}{l}\text { M: Decoction to treat } \\
\text { constipation }\end{array}$ & 1 & \\
\hline & & & & & $\begin{array}{l}\text { M: Decoction to treat } \\
\text { abdominal pain }\end{array}$ & 1 & \\
\hline $\begin{array}{l}\text { Sorbus domestica L. } \\
\text { (Rosaceae) }\end{array}$ & Sharbui (F) & 1 & 0 & Fruits & F: Raw as a snack & 1 & \\
\hline $\begin{array}{l}\text { Stellaria media (L.) Vill. } \\
\text { (Caryophyllaceae) }\end{array}$ & Stellaria & 0 & 1 & $\begin{array}{l}\text { Aerial } \\
\text { parts }\end{array}$ & F: Boiled & & 1 \\
\hline Symphytum officinale L. & Consolida & 1 & 1 & Leaves & F: Omelets & 1 & 1 \\
\hline (Boraginaceae) & & & & & M: Infusion (it is healthy)* & & 1 \\
\hline & & 5 & 3 & & F: Omelets & 5 & 3 \\
\hline (Asteraceae) & Salvia Romana & & & Leaves & F: Soups & & 1 \\
\hline & & & & & F: Infusion in grappa & 1 & 2 \\
\hline & & 8 & 14 & Aerial & F: Omelets & 6 & 14 \\
\hline & & & & parts & F: Infusion in grappa & 1 & 1 \\
\hline
\end{tabular}


This is the postprint version of the article:

Mattalia, G., Soukand, R., Corvo, P., \& Pieroni, A. (2020 Dissymmetry at the Border: Wild Food and Medicinal Ethnobotany of Slovenes and Friulians in Northeast Italy Economic Botany, 10.1007/s12231-020-09488-y.

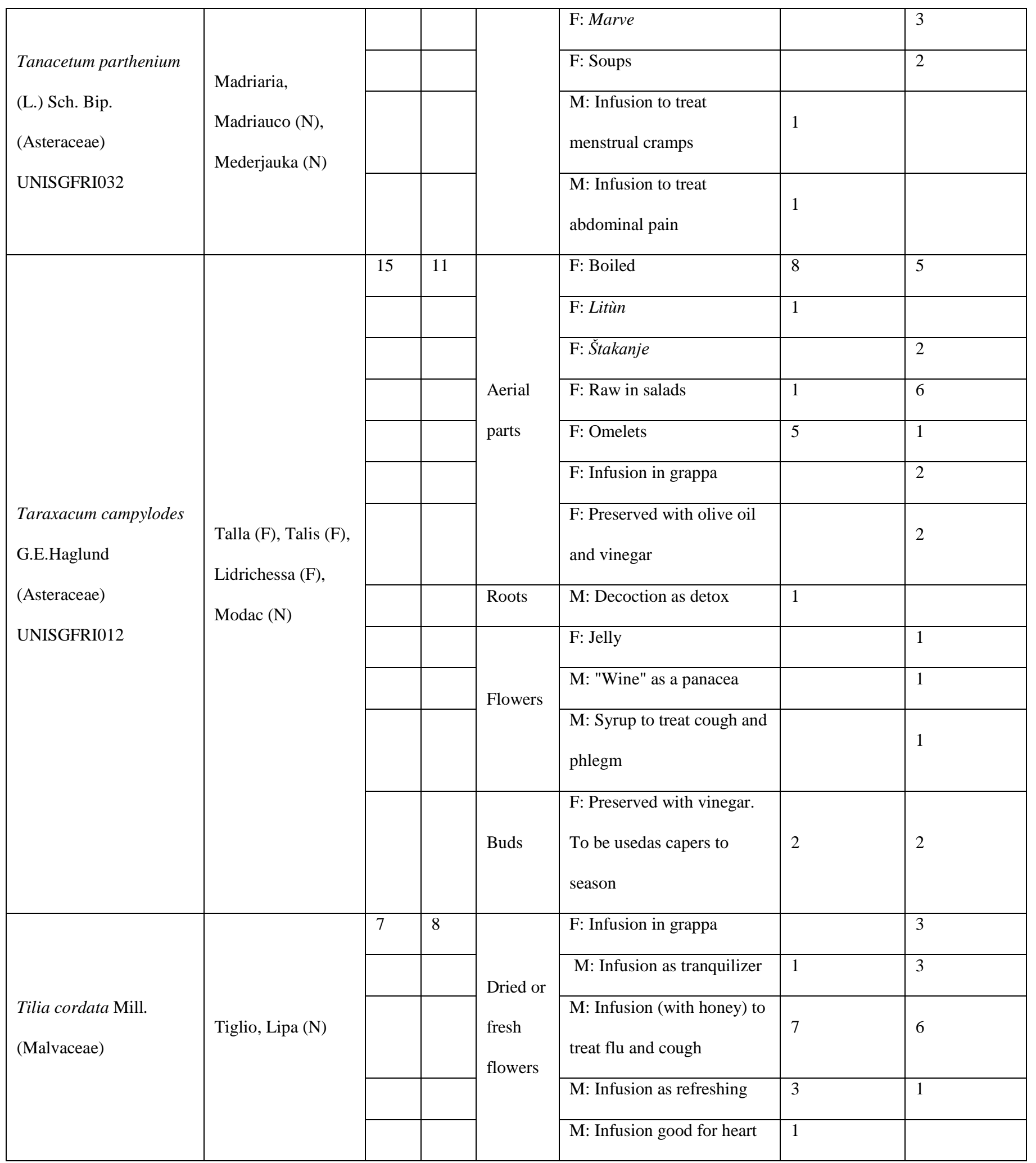


This is the postprint version of the article:

Mattalia, G., Soukand, R., Corvo, P., \& Pieroni, A. (2020 Dissymmetry at the Border: Wild Food and Medicinal Ethnobotany of Slovenes and Friulians in Northeast Italy Economic Botany, 10.1007/s12231-020-09488-y.

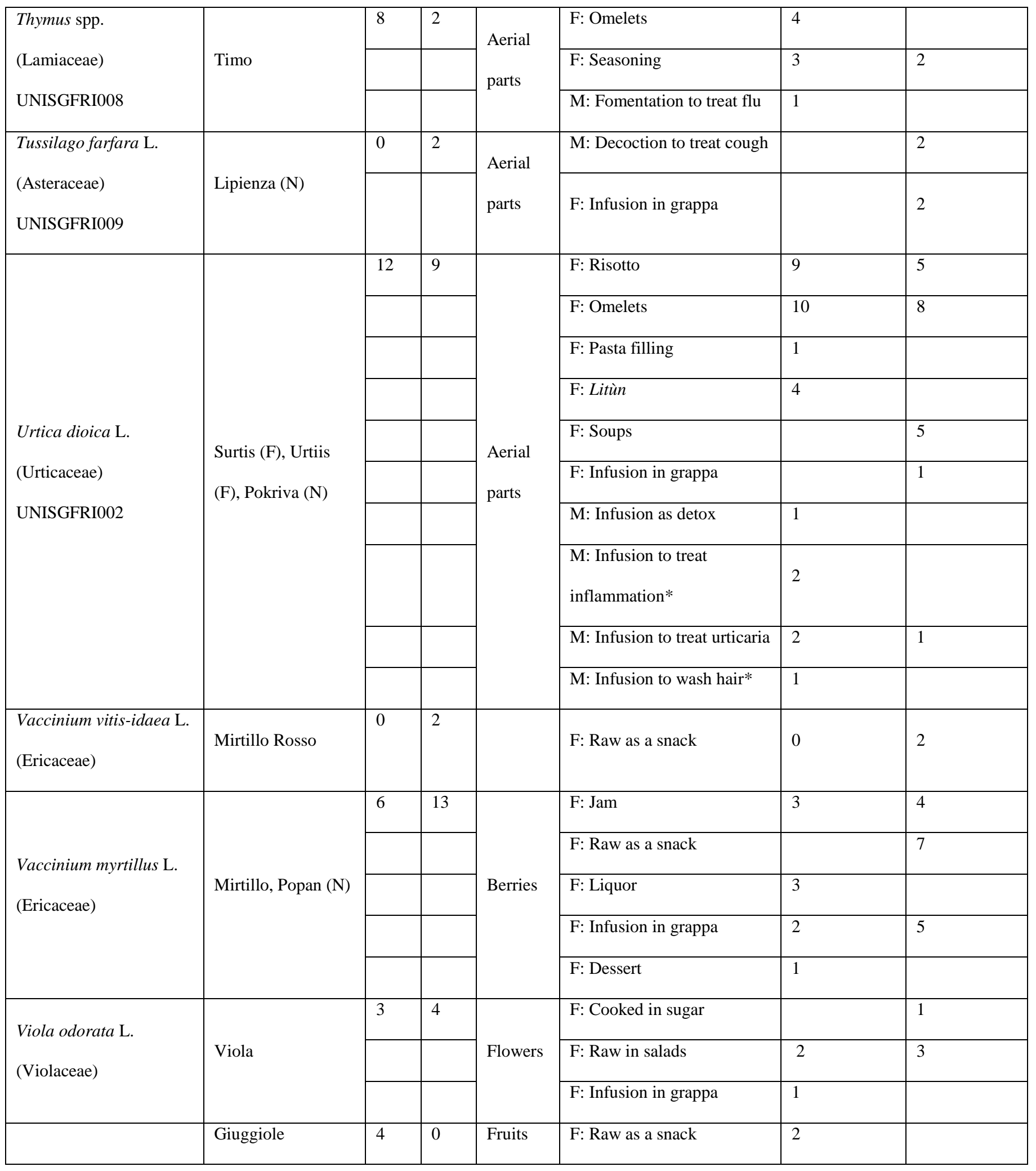


This is the postprint version of the article:

Mattalia, G., Soukand, R., Corvo, P., \& Pieroni, A. (2020 Dissymmetry at the Border: Wild Food and Medicinal Ethnobotany of Slovenes and Friulians in Northeast Italy Economic Botany, 10.1007/s12231-020-09488-y.

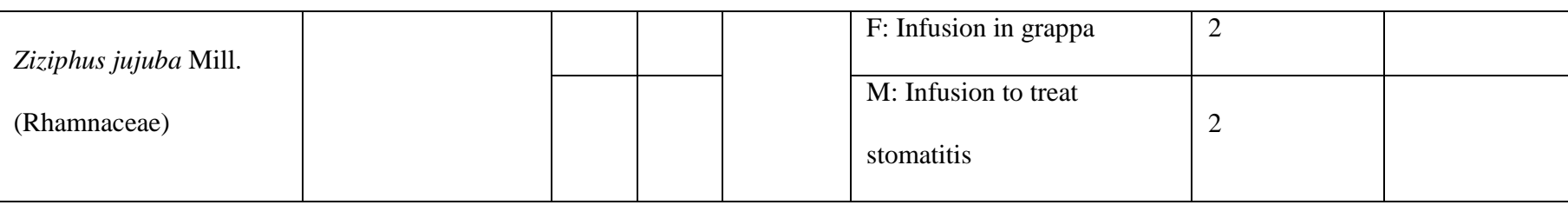

